\title{
Interregional Mobility of Latin American Immigrants in Canada: Explorations Using Tax Filer Data ${ }^{1}$
}

Fernando Mata

School of Sociological and Anthropological Studies

University of Ottawa

fmata_uottawa@yahoo.com

December 3, 2021

\section{Abstract}

Using data from the Longitudinal Immigration Database (IMDB), which links tax filer information to provinces of landing information and current regions, the author carried out data explorations regarding the interregional mobility of 98,440 Latin American immigrants arriving in Canada between 2000 and 2014. These were observed in the tax year 2014. The interregional mobility of citizens from 15 citizenship countries was examined: Argentinians, Bolivians, Brazilians, Chileans, Colombians, Cubans, Ecuadorians, Salvadoreans, Guatemalans, Hondurans, Mexicans, Nicaraguans, Peruvians, Uruguayans, and Venezuelans. Immigrants were allowed entry into Canada under various immigrant intake classes such as economic, family, and refugee. Examination of retention and net migration rates showed that Alberta and British Columbia were among those who benefited the most from Latino immigrant inflows during the observation period. About one in five Latinos had moved outside their original landing region by the tax year 2014. Citizens of various nationalities left the Atlantic, Quebec and Manitoba regions for other ones. Interregional mobility was found the highest among males, earlier arrival cohort members, those with higher educational levels and economic principal applicants. Colombian citizens were the most mobile group while Nicaraguans, Bolivians, and Ecuadorians were the least mobile. The regional triangle constituted by Alberta, Ontario, and Quebec was found to be the dominant one in the network of all migratory exchanges. Tracking the interregional mobility of Latin American immigrants to Canada after arrival provides interesting insights into how this particular immigrant population is redistributed, how it may respond to the needs of regional economies, and also speaks to the success of immigrant integration and resettlement of Latin American immigrants in particular regions of Canada.

\section{Keywords: Interregional Mobility, Latin American Immigrants, Tax Filers, Canada}

\subsection{Introduction}

Latin Americans arrive in Canada not only to escape political instability or violence but also in search of economic opportunities and social mobility (Simmons, 1993). As push-related factors have become stronger, the number of immigrants to Canada from Latin America has also substantially increased over the years. According to Canadian immigration statistics, about 2.5 million permanent residents were admitted to Canada between 2007 and 2016 (IRCC, 2017). Colombia, Mexico, Brazil, and Venezuela topped the list of permanent residents coming from the Latin American region (39.8, 36.3, 19.2, and 12.2 thousand individuals). During the 2003-2012

\footnotetext{
1 Background paper presented to the International Conference Women, Gender and Intersectionality in the Lusophone World, June 29 to July 2, 2022, Ponta Delgada, Azores, Portugal. The author would like to thank Jennifer Dumoulin and the Census Division of Statistics Canada for making available the data and their valuable support and guidance.
} 
period, the number of refugee claimants from Mexico and Colombia totaled approximately 37.5 and 17.5 thousand, respectively. Other major citizenship countries of claimants came from El Salvador, Honduras, Guatemala, and Cuba (CIC, 2014).

The 2000-2014 period represents a historical juncture characterized by the extraordinary growth of the Latino immigrant population in Canada. Nearly a quarter of a million Latin Americans (about 243 thousand) entered Canada as permanent residents from the 15 major countries of citizenship (see Table 1). Colombians (28\%), Mexicans (18\%), and Brazilians (9\%) topped the list of newcomer arrivals for the period. Immigrants from Latin America were allowed entry into Canada under various immigrant intake classes such as economic, family, and refugee $^{2}$. Seen in a broader historical-demographic context, Canadian scholars have conceptualized Latin American immigration to Canada as the product of five major immigrant waves which have reproduced themselves over time and taken various forms(Mata 1985; Garay, 2000; Veronis, 2010; Landolt, Bernhard and Goldring, 2011; Goldring and Landolt,.2021). Immigrant waves from Latin America to Canada have risen or fallen as a consequence of the strength or weakness of migratory push-pull factors affecting the region and Canadian immigration policy goals developed in response to them (Armony, 2014). Currently, Canada is experiencing the arrival of members of the fifth "technological-professional" wave which was preceded in time by the Central American, Coup, Andean, and Lead or Eurolatino waves respectively (Mata, 1985; 2020). This wave comprises a mixed group of individuals ranging from highly skilled workers drawn from the $\mathrm{STEM}^{3}$ industries of the region to individuals of lower educational profiles who regularized their status after being previously admitted as visitors, temporary workers, students, and/or refugee claimants.

Although Latino immigrants have been arriving significantly in large numbers to Canada since the late 1960s, their secondary migration (i.e. the migration occurring after arrival to the host country) is relatively an understudied subject. Why do some Latin American immigrants decide to move inter-regionally after arriving in Canada? This is an important question because to cross-regional boundaries, Latino immigrants must overcome significant distance, institutional, and linguistic-related barriers. Migration decisions of immigrants in their new countries are closely tied to the perceived cost and benefit of moving elsewhere (Richmond, 1988; Nogle,1994; Zavodny, 1999; Aslund and Olof-Ruth, 2007). Costs may range from losing access to local welfare, housing, and social services to leaving established social networks and government. Benefits may include better, higher-paying jobs and being closer to co-ethnics residing in the major urban centers of the host societies (Dahl and Sorensen, 2010). Regional business cycles have also been linked to secondary migration (Orrenius and Zavodny, 2009). Before the fall of oil prices, resource-rich Canadian provinces such as Alberta and Saskatchewan have experienced economic "booms" leading to increased in-migration of skilled and non-skilled immigrant labour force from the Atlantic Provinces, Quebec, and Ontario. Demographic literature also suggests that the presence of family, friends, and co-ethnics, often triggers regional in- and out-migration (Chiswick and Miller, 2005).

\footnotetext{
2 The economic class comprises of individuals such as skilled workers, business immigrants and/or sponsored dependents of skilled workers. The first two are selected via a point system, which assigns scores based on level of education, work experience, skills relevant for work in preferred occupations and knowledge of a Charter language (English or French). The family category comprises immigrants with immediate family members already living in Canada and are required to have a sponsor (typically the family member) who has agreed to provide financial support for a period of three to ten years following arrival. The refugee category comprises three types of refugees (state sponsored, privately sponsored and asylum (e.g. protected persons).

${ }^{3}$ STEM refers to the Science, Technology, Engineering and Mathematics sectors.
} 
Table 1: Permanent Residents Admitted to Canada 2000-2014, Latin American Region, 15 Major Countries of Citizenship (Ranked by Volume)

\begin{tabular}{|c|c|c|c|c|c|c|c|c|c|c|c|c|c|c|c|c|}
\hline Year & 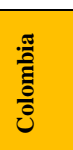 & 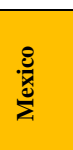 & $\underset{\overparen{D}}{\bar{D}}$ & $\stackrel{\Xi}{2}$ & 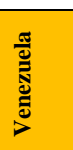 & $\frac{\pi}{3}$ & 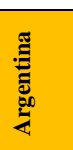 & 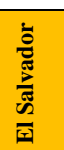 & t⿱丷⿹弔巳 & 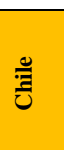 & 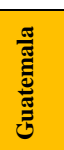 & $\begin{array}{l}\stackrel{\mathscr{J}}{\Xi} \\
\stackrel{\Xi}{\Xi} \\
\text { : }\end{array}$ & $\underset{\Xi}{\vec{z}}$ & 晃 & 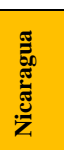 & 퐁 \\
\hline 2000 & 3,226 & 1,658 & 842 & 607 & 475 & 855 & 455 & 552 & 384 & 273 & 142 & 104 & 101 & 93 & 69 & 11,836 \\
\hline 2001 & 4,273 & 1,939 & 857 & 852 & 572 & 971 & 625 & 446 & 306 & 341 & 155 & 112 & 143 & 91 & 68 & 13,752 \\
\hline 2002 & 4,438 & 1,918 & 759 & 858 & 554 & 866 & 845 & 469 & 417 & 357 & 168 & 115 & 109 & 63 & 74 & 14,012 \\
\hline 2003 & 4,473 & 1,738 & 865 & 1,021 & 710 & 876 & 1,783 & 441 & 380 & 343 & 178 & 113 & 108 & 63 & 82 & 15,177 \\
\hline 2004 & 4,438 & 2,245 & 934 & 1,455 & 1,259 & 857 & 1,648 & 437 & 506 & 375 & 217 & 132 & 149 & 98 & 62 & 16,816 \\
\hline 2005 & 6,031 & 2,854 & 976 & 1,658 & 1,235 & 979 & 1,169 & 428 & 561 & 392 & 192 & 160 & 294 & 137 & 75 & 19,146 \\
\hline 2006 & 5,813 & 2,830 & 1,209 & 1,479 & 1,220 & 1,044 & 894 & 421 & 620 & 452 & 215 & 160 & 202 & 149 & 90 & 18,804 \\
\hline 2007 & 4,833 & 3,224 & 1,759 & 1,375 & 1,373 & 1,338 & 624 & 973 & 591 & 546 & 260 & 177 & 175 & 111 & 67 & 19,433 \\
\hline 2008 & 5,449 & 2,853 & 2,137 & 1,094 & 1,239 & 1,300 & 540 & 1,114 & 437 & 350 & 263 & 185 & 159 & 142 & 123 & 17,385 \\
\hline 2009 & 4,652 & 3,092 & 2,509 & 1,881 & 1,352 & 1,426 & 467 & 841 & 373 & 375 & 264 & 169 & 99 & 214 & 114 & 17,828 \\
\hline 2010 & 5,218 & 3,861 & 2,598 & 1,282 & 998 & 961 & 459 & 768 & 353 & 340 & 265 & 385 & 93 & 180 & 91 & 17,852 \\
\hline 2011 & 4,366 & 3,947 & 1,508 & 886 & 1,451 & 961 & 278 & 690 & 348 & 174 & 288 & 538 & 81 & 86 & 122 & 15,724 \\
\hline 2012 & 3,736 & 4,227 & 1,642 & 787 & 1,366 & 1,301 & 263 & 641 & 279 & 291 & 358 & 436 & 47 & 83 & 106 & 15,563 \\
\hline 2013 & 3,633 & 3,995 & 1,712 & 683 & 1,022 & 1,401 & 282 & 637 & 418 & 273 & 348 & 350 & 58 & 107 & 96 & 15,015 \\
\hline 2014 & 2,859 & 4,478 & 1,916 & 712 & 1,483 & 1,079 & 214 & 700 & 334 & 299 & 317 & 401 & 43 & 95 & 118 & 15,048 \\
\hline $\begin{array}{l}\text { Total } \\
2000-2014\end{array}$ & 67,438 & 44,859 & 22,223 & 16,630 & 16,309 & 16,215 & 10,546 & 9,558 & 6,307 & 5,181 & 3,630 & 3,537 & 1,861 & 1,712 & 1,357 & 243,391 \\
\hline Percentage & $28 \%$ & $18 \%$ & $9 \%$ & $7 \%$ & $7 \%$ & $7 \%$ & $4 \%$ & $4 \%$ & $3 \%$ & $2 \%$ & $2 \%$ & $2 \%$ & $1 \%$ & $1 \%$ & $1 \%$ & $100 \%$ \\
\hline
\end{tabular}

Sources: IRCC Facts and Figures:2004; IRCC Facts and Figures 2017: Immigration Overview - Permanent residents, table 15

In 2016, approximately $38 \%$ of the Canadian population, and 51\% of the foreign-born population resided in the region of Ontario. Large concentrations of immigrants were also present in the British Columbia, Quebec, and Prairie regions $(18 \%, 14 \%$, and $13 \%$ respectively). The large metropolitan regions where co-ethnics are concentrated constitute the typical residential "magnets" for different types of immigrant class members such as economic class, family, and refugee streams (Houle, 2004; Hou, 2011; Bonikowska et. al. 2015). Metropolitan centers such as Toronto (Ontario region), Montreal (Quebec region), and Vancouver (British Columbia region) offer a wide range of social and economic opportunities which are highly attractive to Latin Americans and other immigrant groups. Calgary and Edmonton in Alberta as well as Winnipeg in Manitoba are also singled out as important "gateway" cities for new immigrants.

Previous studies carried out with longitudinal data on the general immigration population conducted with immigrant cohorts arriving between 1991-2006 as well as between 2008-2013 have shown that the Alberta and Ontario regions were the typical "winners" of migratory interchanges while the Atlantic and Quebec regions were the typical "losers" (Okono-Myers, 2010; van Huystee, 2016). Several research questions come to mind related to the immigration of Latin Americans during the 2000-2014 growth period: Has this population followed the same interregional mobility patterns as the general immigrant population? What is the general picture in terms of retention rates and migratory exchanges of Latino immigrants across Canadian regions? What are the most typical origin and destination regions for Latino immigrants in Canada? What gender, intake class, and citizenship groups differentials are the most noticeable? Using tax filer information from the Longitudinal Immigrant Database (IMDB) administered by Statistics Canada, this paper addresses these broad research questions by exploring information on interregional movements captured in the IMDB database of tax filers. 


\subsection{Data, Country Selection and Research Activities}

The IMDB provides an excellent opportunity to examine the secondary migration patterns of Latin American immigrants through its unique linkage between the information captured by both the immigration and taxation programs ${ }^{4}$. Immigrants are identified through information provided on their confirmation of permanent residency documents at the landing and allows for the tracking (on an annual basis) of the location of those immigrants through both the province and postal code information provided on their tax returns ${ }^{5}$.

A special table (SCS-504) was drawn from the IMDB master file of immigrant tax filers ${ }^{6}$. This table provided detailed information on the region of the landing of immigrants, age, gender, educational levels, immigrant intake categories of admission (economic, family, and refugee), country of citizenship of immigrants as well as several tax reporting years. For this analysis, immigrant tax filers landing in Canada between 2000-2014 from 15 major citizenship countries of Latin America were chosen for analysis. These were citizens from Argentina, Bolivia, Brazil, Chile, Colombia, Cuba, Ecuador, El Salvador, Guatemala, Honduras, Mexico, Nicaragua, Peru, Uruguay, and Venezuela ${ }^{7}$. Within the context of the IMDB data definitions, interregional mobility is approximated by the difference between an immigrant's stated region of destination at the time he or she was admitted as a permanent resident to Canada and his or her place of residence at the 2014 tax year. The 2014 tax year was chosen to study the early, middle, and later periods of settlement of three arrival cohorts: 20002004, 2005-2009, and 2010-2014. It should be noted that only individuals aged 25 to 64 during the 2014 tax reporting year are included in the present analysis. Seven regions of the landing were examined: Atlantic (comprising 4 provinces: New Brunswick, Newfoundland and Labrador, Nova Scotia, and Prince Edward Island), Quebec, Ontario, Manitoba, Saskatchewan, Alberta, and British Columbia (B.C).

To examine the patterns of interregional mobility of Latin American immigrant tax filers, three main research activities were undertaken. These entailed: 1) calculating regional retention rates (RRs) by various sociodemographic and administrative markers of immigrants $\left.{ }^{8}, 2\right)$ calculating net migration rates to identify Canadian regions that benefited from the residential changes of Latino tax filers during the observation period, and 3) pinpointing the typical origins and destinations of Latino immigrants ${ }^{9}$. In demographic analysis, retention rates are used as indicators of residential preferences and, in the case of immigrant groups, sometimes

\footnotetext{
4 This dataset is currently administered by Statistics Canada. For more information on the IMDB please visit https://www23.statcan.gc.ca/imdb/p2SV.pl?Function=getSurvey\&SDDS=5057 .

5 Immigrants who do not file tax returns (for example, children), or for whom the linkage between the immigration and tax system failed, are absent from the database and are not accounted for in the number of movers and non-movers or in the calculation of migration rates presented in this profile. As a result, the actual number of movers and non-movers would be higher than that reported for tax filers. It should also be noted that immigrants who left the country or do not file a tax return in the year of observation are also not accounted for in any calculations.

6 Release date to the author: October 2021. Note: the table counts in the special IMDB table are rounded to 0 or 5.

7 Immigrant counts for countries such Paraguay, Dominican Republic, Costa Rica and Panama were considered too low during the observation period, and thus, were excluded from the sample

8 "Movers" are said to be individuals who change their place of residence because moving benefits exceed costs, either because they have much to gain by moving or because they placed unusually low weight on the potential gains from staying in their current place of regional residence (Dahl and Sorensen, 2010). "Stayers", on the other hand, represent population segments that have decided to remain in their current residence and/or postpone their migration decisions.

9 This research involved an intensive analysis of origin-destination matrices $(7 \times 7)$ calculated for different genders, immigrant intake classes and countries of citizenship.
} 
to assess the relative success of immigrant settlement programs and interventions. Net migration rates (NMRs) are also useful demographic indicators as they provide information on net regional gains or losses (e.g. people arriving minus those leaving a given geographical area) relative to the intended immigrant population at arrival).

\subsection{IMDB Data Definitions}

The following IMDB data definitions are used in the paper:

Destined at Landing: The total number of immigrants admitted as permanent residents intended for the regions arriving between 2000 and 2014 and observed in the tax year 2014.

Out-Migration from a Region: Total number of immigrants, who landed in a region between 2000 and 2014 and who still resided in Canada but not in their destination region in the tax year 2014, by region of destination.

In-Migration to a Region: Total number of immigrants who landed in a region between 2000 and 2014 who were not destined to the region in which they resided in the tax year 2014, by region.

Destined and Resident in the Tax Year 2014: Total number of immigrants who landed between 2008 and 2014 and who still resided in their destination region in the tax year 2014 .

Retention Rate (RR): The percentage of immigrants who arrived between 2000 and 2014 who resided in their region of destination in the tax year 2014, by region. Lower retention rates signal greater interregional mobility. Net Migration Rate (NMR): The number of in-migrants to a particular region less those who left the region for another region over the destined landing population (expressed as a percentage). Positive rates signal greater population gains relative to the destined population at landing, negative rates are the opposite.

\subsection{Tax Filer Sample}

A total of 98,440 Latin American tax filers were captured by the IMDB data (45,293 males and 53,158 females) and observed in the tax year 2014. Females were slightly over-represented in the sample ( $54 \%$ compared to $46 \%$ of males). About one in five (26\%) arrived in Canada between 2000-2004, 43\% between 2005-2009, and 31\% between 2010-2014. Chart 1 displays the country of citizenship composition (\%) of the tax filer sample. Individuals from Colombia and Mexico accounted for about half of the sample (29\% and $21 \%$ respectively). Other major countries of citizenship included Brazil (10\%), Peru (7\%), Venezuela (7\%), and Cuba (7\%).

Table 2 presents several socio-demographic and administrative characteristics of Latino tax filers at the time of their arrival to Canada. The most educated individuals were citizens from Venezuela and Brazil, about $75 \%$ and $72 \%$ of them respectively had a bachelor's degree or higher at arrival to Canada. Relative lower levels of education were noticeable among Hondurans and Salvadorean citizens (63\% and 61\% had secondary education or lower levels upon arrival to Canada). In terms of immigrant intake class country differentials, immigrants from countries such as Venezuela (72\%), Argentina (70\%) and Brazil (66\%) entered mostly as economic class entrants. Higher proportions of family class entrants were visible among individuals coming from Nicaragua (63\%), Ecuador (58\%), and Cuba (52\%). In terms of refugee class entrants, more than half of Colombians (54\%) and more than a third (35\%) of Mexicans had arrived as refugees.

About $40 \%$ of the tax filer sample landed in the Ontario region, 37\% in the Quebec region, and the remaining $13 \%$ in the other 
regions of the country (see Chart A-1 in the Appendix). Examining the residential preferences at landing, the Ontario region was the most preferred destination for Ecuadorians, Uruguayans, Cubans, and Nicaraguans (at least 50\% of them chose this particular region of residence). The Quebec region was particularly attractive to Peruvians (54\%). Citizens from Central American countries such as Guatemala, Honduras, Mexico, and El Salvador chose British Columbia (17\% each) as their landing destination more frequently when compared to other groups. Similarly, citizens from Honduras and El Salvador did so for Manitoba (16\% each). The majority of tax filers declared their 2014 taxes from the Central Metropolitan Areas ${ }^{10}$ (89\%) of the seven Canadian regions. Relatively lower proportions were observed for citizens from Bolivia, El Salvador, Honduras, and Mexico (75\% to 85\%) compared to other groups.

In terms of income profiles in the sample, Chart A-2 in the Appendix presents the median employment incomes (before taxes) of tax filers by gender and country of citizenship. Notable gender gaps in taxable incomes are observable between males and females. On the higher side of the spectrum, the median of taxable employment incomes reported for groups such as Venezuelan and Brazilian males surpassed the \$ Can 100 thousand mark, while the taxable incomes of the majority of women did not exceed \$ Can 70 thousand.

Chart 1: Latin American Immigrant Tax Filers: Countries of Citizenship (\%), Tax Year 2014, 2000-2014 Landings

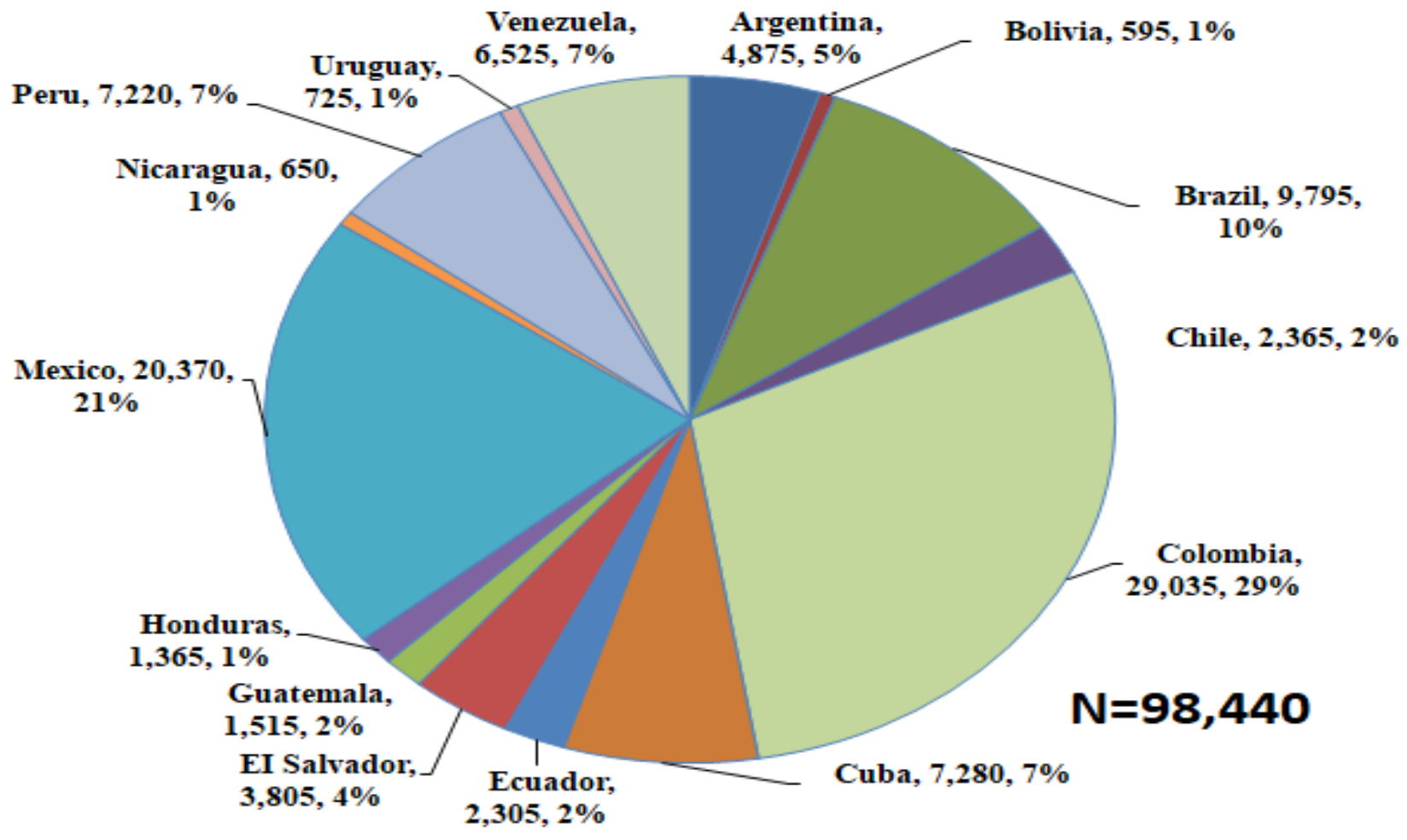

Source: Special Table SCS-504, Longitudinal Immigration Database (IMDB).

\footnotetext{
${ }^{10}$ According to Statistics Canada a census metropolitan area (CMA) is formed by one or more adjacent municipalities centred on a population centre (known as the core). A CMA must have a total population of at least 100,000 of which 50,000 or more must live in the core.
} 
Table 2: Latin American Immigrant Tax Filers: Gender, Educational and Immigrant Intake Class Composition at Arrival, Tax Year 2014, 2000-2014 Landings (Ranked by Volume)

\begin{tabular}{|c|c|c|c|c|c|c|c|}
\hline Citizenship & Counts (N) & \% Females & $\begin{array}{c}\text { \% Secondary } \\
\text { Education or } \\
\text { less at } \\
\text { admission }\end{array}$ & $\begin{array}{c}\% \text { With a } \\
\text { bachelor } \\
\text { degree or } \\
\text { higher }\end{array}$ & $\begin{array}{c}\% \\
\text { Economic } \\
\text { Class } \\
\text { (a) }\end{array}$ & $\begin{array}{l}\text { \% Family } \\
\text { Class }\end{array}$ & $\begin{array}{c}\quad \% \\
\text { Refugee } \\
\text { Class (a) }\end{array}$ \\
\hline All Countries & 98,440 & $54 \%$ & $27 \%$ & $55 \%$ & $44 \%$ & $29 \%$ & $25 \%$ \\
\hline Colombia & 29,035 & $54 \%$ & $30 \%$ & $53 \%$ & $34 \%$ & $11 \%$ & $54 \%(b)$ \\
\hline Mexico & 20,370 & $54 \%$ & $26 \%$ & $56 \%$ & $40 \%$ & $40 \%$ & $17 \%$ \\
\hline Brazil & 9,795 & $56 \%$ & $14 \%$ & $72 \%$ & $66 \%$ & $31 \%$ & $1 \%$ \\
\hline Cuba & 7,280 & $50 \%$ & $25 \%$ & $45 \%$ & $29 \%$ & $52 \%$ & $19 \%$ \\
\hline Peru & 7,220 & $57 \%$ & $18 \%$ & $57 \%$ & $48 \%$ & $33 \%$ & $17 \%$ \\
\hline Venezuela & 6,525 & $54 \%$ & $12 \%$ & $75 \%$ & $72 \%$ & $17 \%$ & $8 \%$ \\
\hline Argentina & 4,875 & $49 \%$ & $22 \%$ & $60 \%$ & $70 \%$ & $21 \%$ & $4 \%$ \\
\hline EI Salvador & 3,805 & $52 \%$ & $61 \%$ & $27 \%$ & $36 \%$ & $42 \%$ & $17 \%$ \\
\hline Chile & 2,365 & $52 \%$ & $30 \%$ & $40 \%$ & $44 \%$ & $46 \%$ & $6 \%$ \\
\hline Ecuador & 2,305 & $59 \%$ & $36 \%$ & $48 \%$ & $32 \%$ & $58 \%$ & $7 \%$ \\
\hline Guatemala & 1,515 & $52 \%$ & $51 \%$ & $30 \%$ & $20 \%$ & $44 \%$ & $35 \%(\mathrm{c})$ \\
\hline Honduras & 1,365 & $56 \%$ & $63 \%$ & $24 \%$ & $44 \%$ & $36 \%$ & $27 \%$ \\
\hline Uruguay & 725 & $50 \%$ & $43 \%$ & $32 \%$ & $39 \%$ & $47 \%$ & $10 \%$ \\
\hline Nicaragua & 650 & $60 \%$ & $48 \%$ & $37 \%$ & $21 \%$ & $63 \%$ & $21 \%$ \\
\hline Bolivia & 595 & $61 \%$ & $28 \%$ & $55 \%$ & $49 \%$ & $37 \%$ & $14 \%$ \\
\hline
\end{tabular}

(a): Includes Spouses and Dependents. (b): $60 \%$ of refugees from Colombia were admitted as protected persons. (c) $75 \%$ of the refugees from Guatemala were admitted as protected persons. Source: Special Table SCS-504, Longitudinal Immigration Database (IMDB).

\subsection{Data Explorations Highlights}

\subsection{Alberta, Ontario and British Columbia displayed the highest retention rates of Latino immigrants, the Atlantic region the lowest one. Manitoba experienced the greatest percentage loss of its original intended Latino immigrant population}

Chart 2 presents the regional retention and net migration rates calculated for Latino tax filers arriving between 2000-2017 and observed at the tax year 2014 ${ }^{11}$. Table 3 provides the calculations upon which this chart is based. Alberta, British Columbia, and Ontario were found to be the most Latino retentive regions of Latin American immigrants (with rates ranging between .89 and .94). The Atlantic region was found as the least retentive: only $53 \%$ of immigrants destined for these regions remained in the same region of landing by the tax year 2014 . The Manitoba region, though having a moderate retentive rate $(\mathrm{RR}=.75)$, experienced the greatest percentage loss of its original intended Latino immigrant population (-23\%).

\footnotetext{
11 Illustrative example: Of the 9,620 Latinos who arrived as permanent residents who landed in Alberta 9,015, still lived in the region in tax year 2014. Thus, the retention rate for this region was $(9015 / 9,620)$ or .94. Between 2000-2014, Alberta received 4,515 new immigrants while 1,065 left the province, leaving a net migration of 3,450 individuals. Expressing this net migration as a percentage of the destined population of landing, the calculated net migration rate $(\%)$ was $\left((3,450 / 9,620)^{*} 100\right)$ or about $+36 \%$.
} 
Chart 2: Latin American Immigrant Tax Filers: Retention and Net Migration Rates (\%) by Regions of Landing and Reporting, tax Year 2014, 2000-2014 Landings

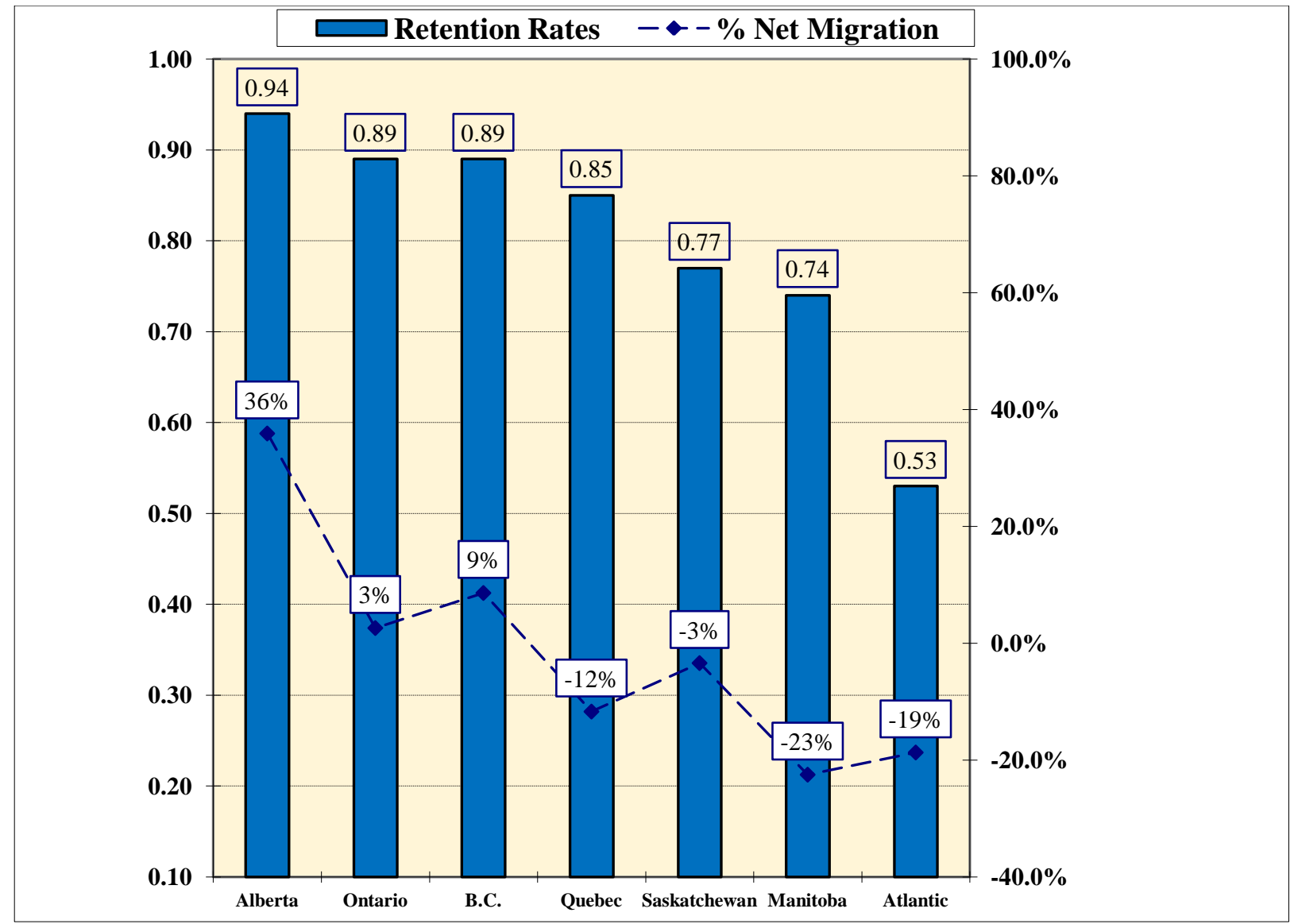

Source: Special Table SCS-504, Longitudinal Immigration Database (IMDB).

Table 3: Interprovincial Mobility of Latin American Immigrant Tax Filers: Retention Rates and Net Migration Rates, tax year 2014, 2000-2014 Landings

\begin{tabular}{|c|c|c|c|c|c|c|c|}
\hline All Tax Filers & $\begin{array}{l}\text { Destined at } \\
\text { Landing } \\
\text { (a) }\end{array}$ & $\begin{array}{l}\text { In- } \\
\text { migration } \\
\text { (b) }\end{array}$ & $\begin{array}{l}\text { Out- } \\
\text { Migration } \\
\text { (c) }\end{array}$ & $\begin{array}{c}\text { Net } \\
\text { Migration } \\
\text { (d)=(b)-(c) }\end{array}$ & $\begin{array}{l}\text { Destined } \\
\text { and } \\
\text { Residing } \\
\text { TX 2014 } \\
\text { (e) }\end{array}$ & $\begin{array}{c}\text { RR; } \\
\text { Retention } \\
\text { Rates } \\
\text { (e)/(a) }\end{array}$ & $\begin{array}{c}\text { \% NMR: } \\
\text { ((d)/(a))x1 } \\
00\end{array}$ \\
\hline Atlantic & 1,215 & 290 & 515 & -225 & 645 & 0.53 & $-18.7 \%$ \\
\hline Quebec & 36,465 & 1,215 & 5,490 & $-4,275$ & 31,150 & 0.85 & $-11.7 \%$ \\
\hline Ontario & 38,795 & 4,590 & 3,595 & 995 & 34,375 & 0.89 & $2.6 \%$ \\
\hline Manitoba & 2,865 & 155 & 800 & -645 & 2,125 & 0.74 & $-22.5 \%$ \\
\hline Saskatchewan & 855 & 235 & 265 & -30 & 665 & 0.77 & $-3.4 \%$ \\
\hline Alberta & 9,620 & 4,515 & 1,065 & 3,450 & 9,015 & 0.94 & $35.9 \%$ \\
\hline British Columbia & 8,575 & 1,855 & 1,125 & 730 & 7,595 & 0.89 & $8.6 \%$ \\
\hline
\end{tabular}

Source: Special Table SCS-504, Longitudinal Immigration Database (IMDB). 


\subsection{Alberta and British Columbia experienced the greatest gains of Latino immigrants across all immigrant intake classes particularly refugees. Colombians and Cubans leaving the Atlantic region, Colombians and Venezuelans leaving the Quebec region, various nationalities leaving Manitoba}

NMRs by region and immigrant intake class categories are presented in Chart 3. Alberta displayed positive rates for economic principal applicants equivalent to a 33\% increase of their intended landing populations and a surprising $112 \%$ in terms of its refugee population. The corresponding figures for the British Columbia region were $+16 \%$ and $+19 \%$ respectively. On the other side of the migratory exchanges spectrum, the strong negative NMRs for the Atlantic region indicate that Latino immigrants left this region in large numbers, individuals admitted as refugees in particular (NMR=44\%). In terms of country of citizenship variations (see chart 4), NMRs for all countries were all found to be positive, ranging from $+9 \%$ to $+40 \%$. The figures of Chart 4 also suggest that the Atlantic region was particularly unattractive for Colombians (NMR=-138\%) while it was found to be attractive to Mexicans (NMR=+29\%). NMRs relative to Quebec suggest this region experienced the greater losses of Colombians (NMR=-20\%) and Venezuelans (-24\%). The Manitoba region experienced losses of Colombians, Brazilians, and Mexicans (NMRs of -33\%, -33\%, and -26\% respectively) while Saskatchewan experienced gains of Mexican tax filers (NMR=+33\%).

Chart 3: Latin American Immigrant Tax Filers: Net Migration Rates (\%) by Immigrant Class and Regions of Landing, tax year 2014, 2000-2014 Landings

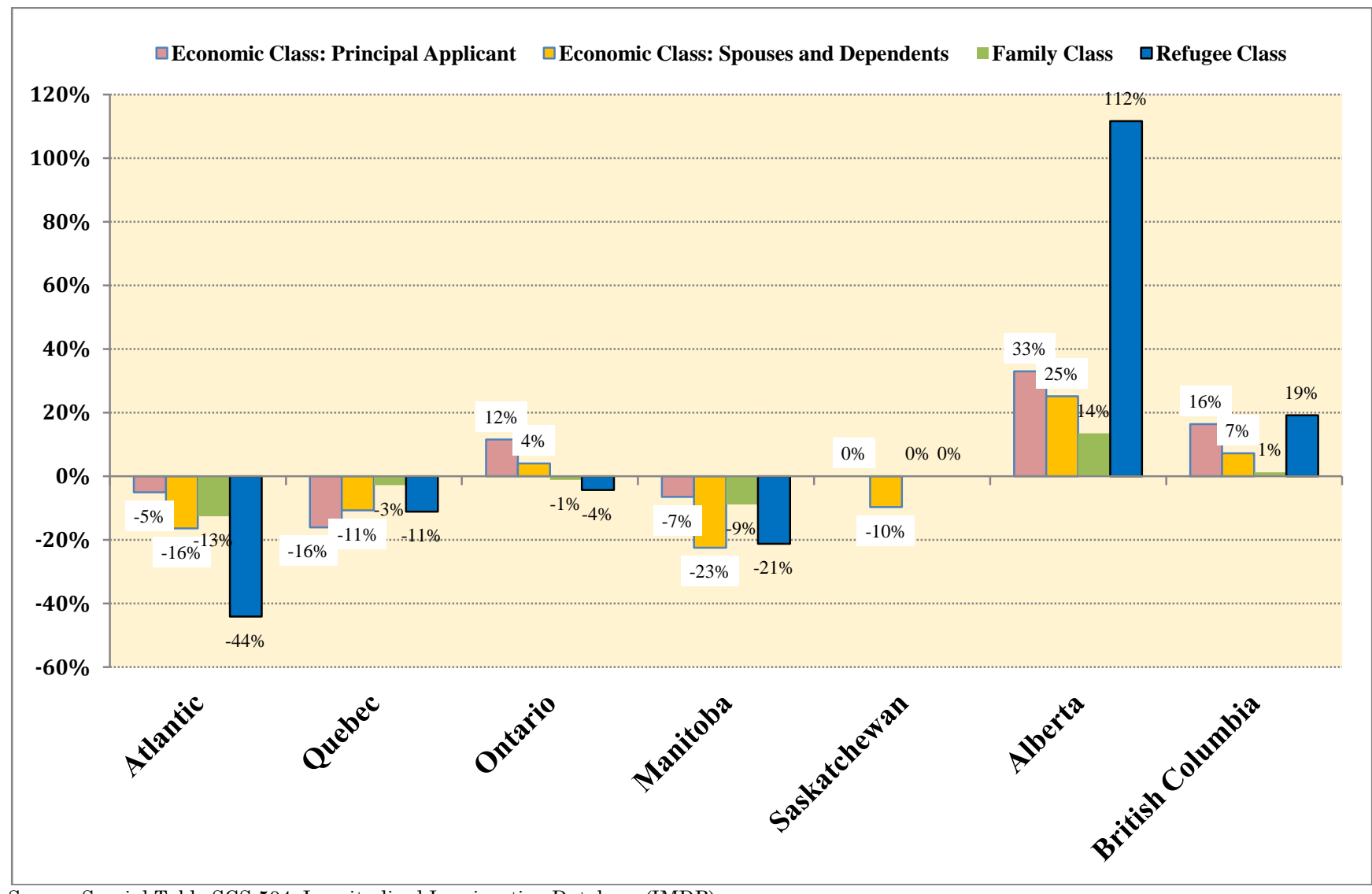

Source: Special Table SCS-504, Longitudinal Immigration Database (IMDB). 
Chart 4: Latin American Immigrant Tax Filers: Net Migration Rates (\%) by Country of Citizenship, Regions of Landing, Tax Year 2014, 2000-2014 Landings

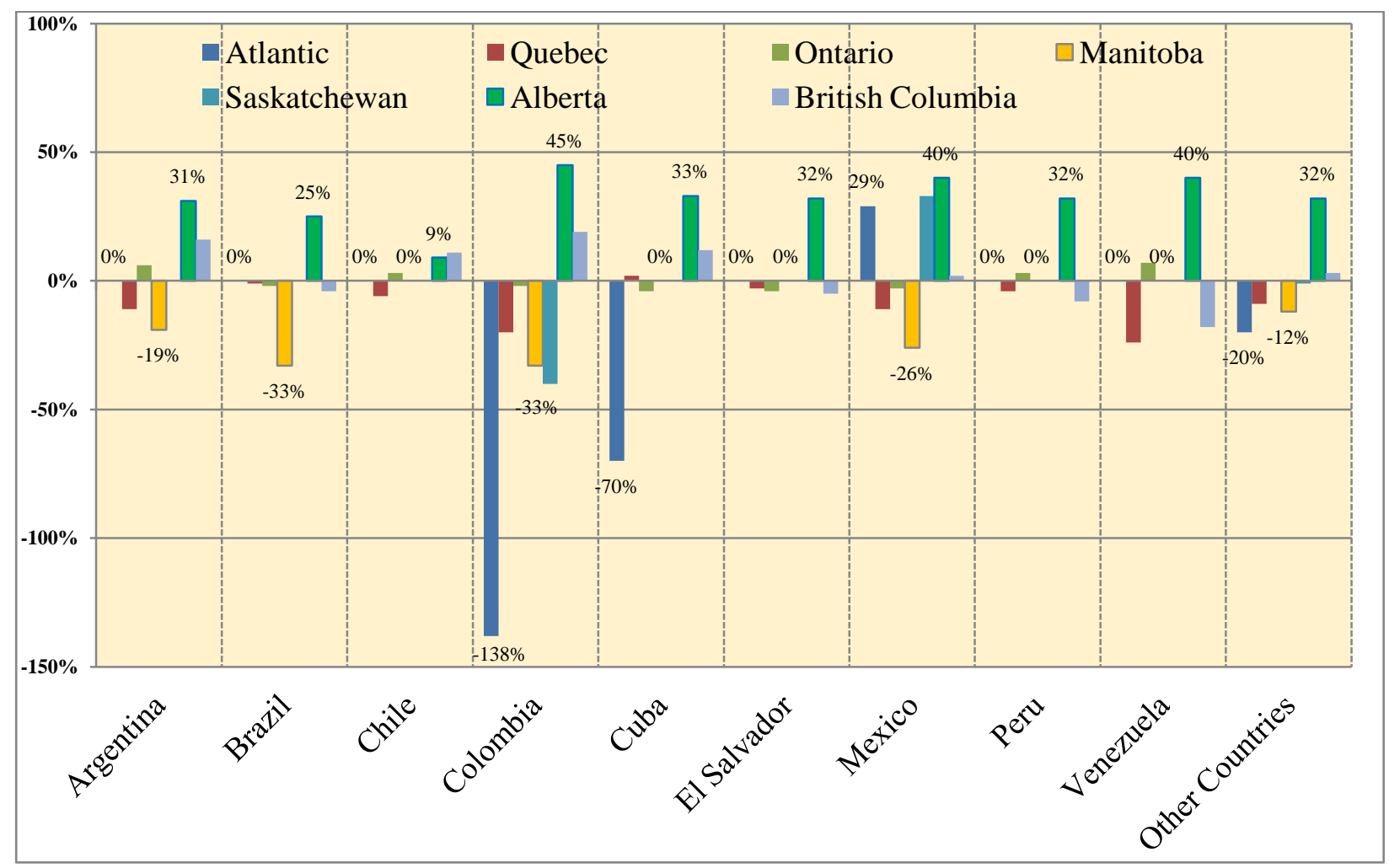

Source: Special Table SCS-504, Longitudinal Immigration Database (IMDB).

\subsection{Interregional mobility was the highest among males, earlier arrival cohort members, those with higher education levels as well as economic class principal applicant immigrants.}

Chart 5 presents the retention rates for Latino immigrants of different socio-demographic and administrative markers at tax year 2014. Four out of five $(80 \%, R R=.80)$ immigrants remained in their intended region of landing by that tax year, while the other $20 \%$ had left for other regions. This is translated into approximately 78,750 interregional "Stayers" and 19,690 interregional "Movers". There were noticeable variations by gender, arrival cohort educational levels, and immigrant intake classes. Males were more migratory than females (lower RRs of .77 compared to .82 of females). The likelihood of mobility also increased with a longer stay in Canada. Immigrants of earlier cohorts such as those arriving 2000-2004 displayed lower retention rates compared to mid-or-later arrival cohorts of 2005-2009 and 2010-2014 (.77 to .85 and .89). On average, those individuals arriving in Canada with a bachelor's degree or higher were more mobile than other educational groups $(R R=.77)$ such as those who arrived with secondary education of lower $(\mathrm{RR}=.88)$. In terms of immigrant intake class, those who arrived as economic class principal applicants were the most mobile $(R R=.75)$ followed by refugees $(R R=.79)$ 
compared to the other groups. Immigrants arriving as the family class $(R R=.91)$ were found as the least mobile of the immigrant class category groups.

Chart 5: Latin American Immigrant Taxfilers: Retention Rates by Major Socio-Demographic and Administrative Markers, tax year 2014, 2000-2014 Landings

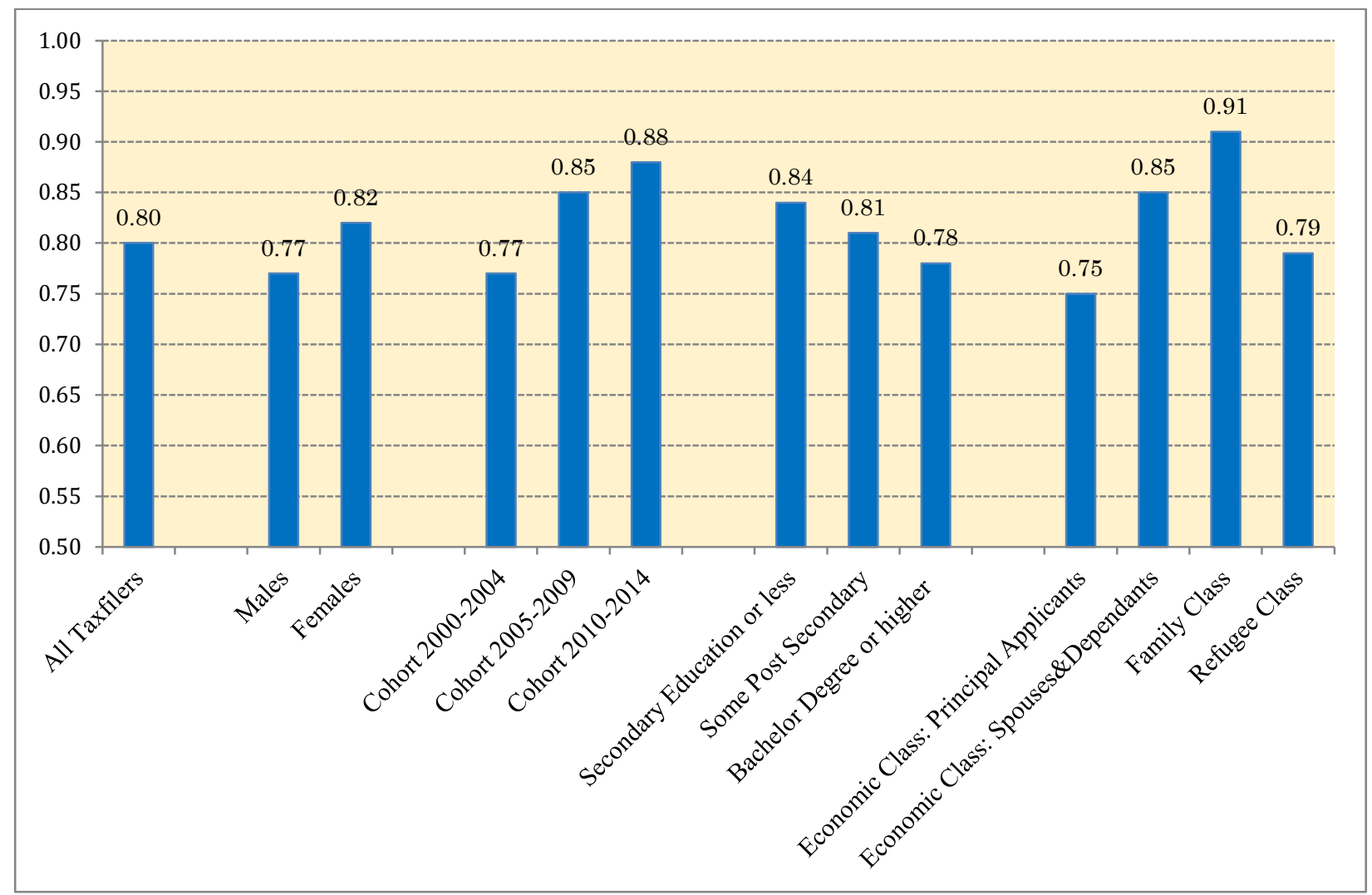

Source: Special Table SCS-504, Longitudinal Immigration Database (IMDB).

\subsection{Colombian citizens were found the most interregional mobile. Nicaraguans, Bolivians and Ecuadorians the least mobile.}

Out of the citizenship groups examined, Colombians were found as the most mobile group (see Chart 6). By 2014, 28\% of them had moved away from their original region of landing $(\mathrm{RR}=.72)$. Lower retention rates were found also for Mexican, Argentinian, Venezuelan and Salvadorean tax filers (RRs ranging from .77 to .79). The highest retention rates were displayed by Chilean, Ecuadorian, Bolivian, and Nicaraguans $(\mathrm{RRs}=.90$ or higher. These have been mostly the typical "stayers" of the Latino immigrant population during the period. Additional information of retention rates broken down by country of citizenship and arrival cohorts suggest that the retention rates decreased monotonically for all arrival groups with a longer stay in the countries (see Chart 7). Colombian, Mexican, and Argentinian tax filers of the earlier arrival cohorts displayed had the lowest retention rates while Hondurans, Uruguayans, and Ecuadorians had the highest. 
Chart 6: Latin American Immigrant Tax Filers: Retention Rates by Country of Citizenship, tax year 2014, 20002014 Landings

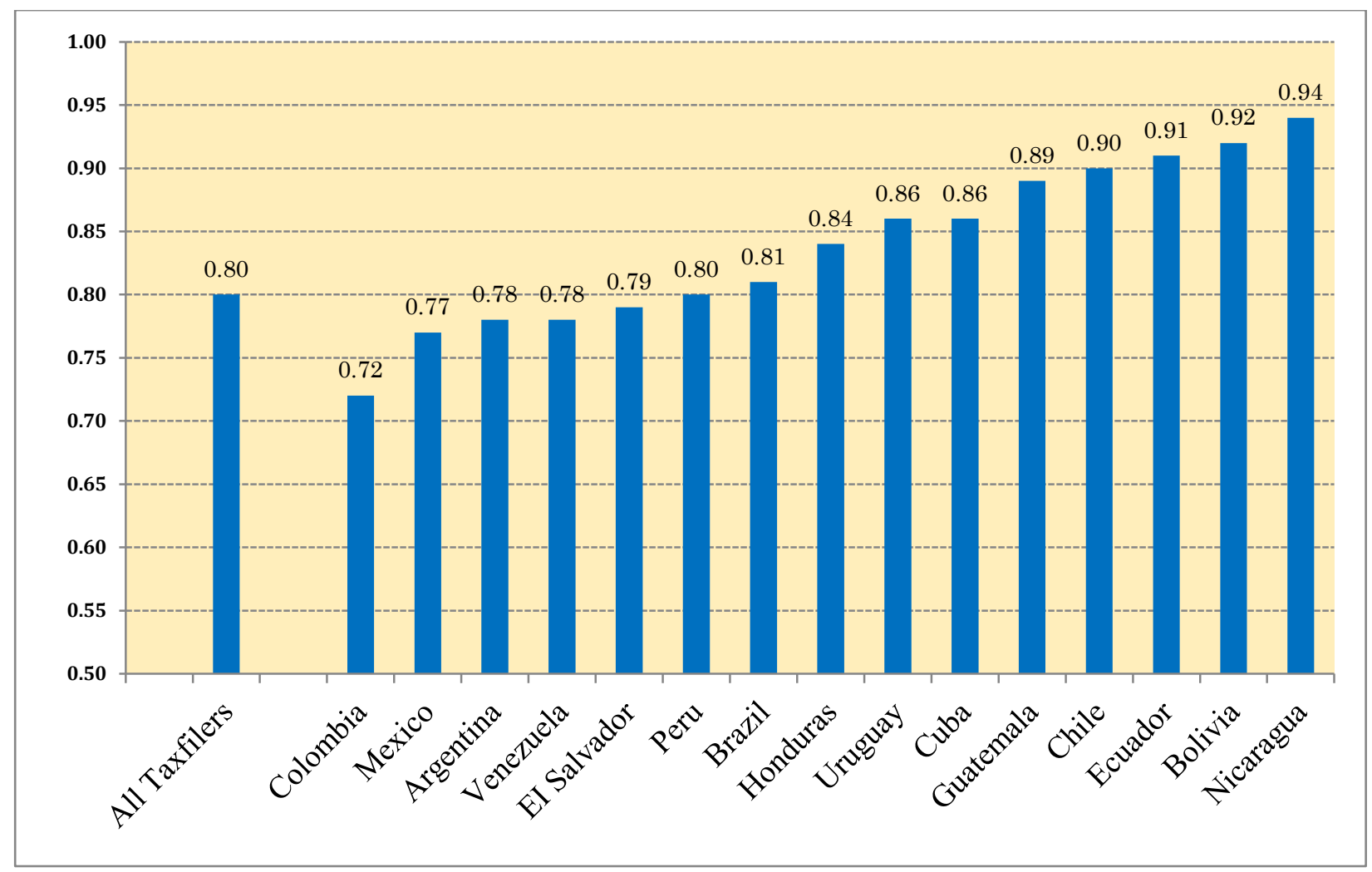

Source: Special Table SCS-504, Longitudinal Immigration Database (IMDB).

Chart 7: Latin American Immigrant Tax Filers: Retention Rates by Arrival Cohorts and Country of Citizenship, tax year 2014, 2000-2014 Landings

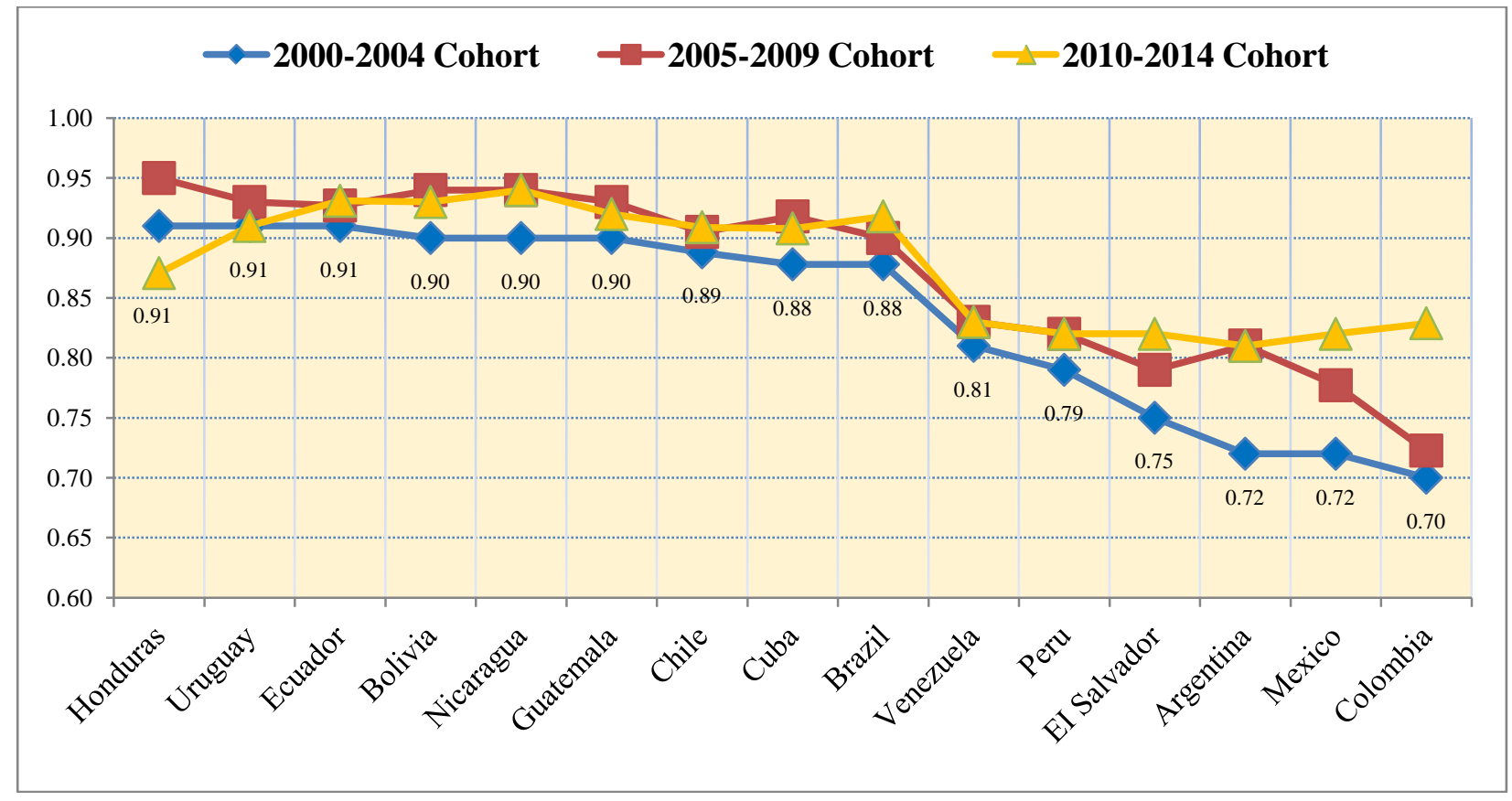

Source: Special Table SCS-504, Longitudinal Immigration Database (IMDB). 


\subsection{The regional triangle constituted by Alberta, Ontario and Quebec was found to be the dominant one in the migratory exchanges network}

Using social network graphing ${ }^{12}$, Chart 8 displays the inflows and outflows of Latino tax filers to and from original regions of landing providing more detailed information on residential changes reported between 2000 and 2014. In the network diagram, the line numbers between vertices (regions) represent counts found outside their regions of landing at tax year 2014. Counts in the lines close to vertices represent inflows to the region, while more distant ones represent outflows from the region. Inspecting this graph, the triangle of mobility exchanges formed by Alberta, Ontario, and Quebec appeared as clearly the most dominant in the network of regional exchanges of Latino immigrants (representing $61 \%$ of the total number of migratory exchanges or about 12,115 movers $)^{13}$. Within this mobility triangle, the exodus of Latinos from Quebec to Ontario is the most noticeable (23\% of all migratory exchanges). The graph shows that about 4,610 immigrants originally destined for Quebec had filed their taxes in Ontario by the tax year 2014. The movement in the opposite direction was of a lesser magnitude: 1,315 individuals originally destined for Ontario filed their taxes in Quebec by 2014.

Chart 8: Latin American Immigrant Tax Filers: Network Chart of Inflows and Outflows*, Regions of Landing and Reporting, tax year 2014, 2000-2014 Landings

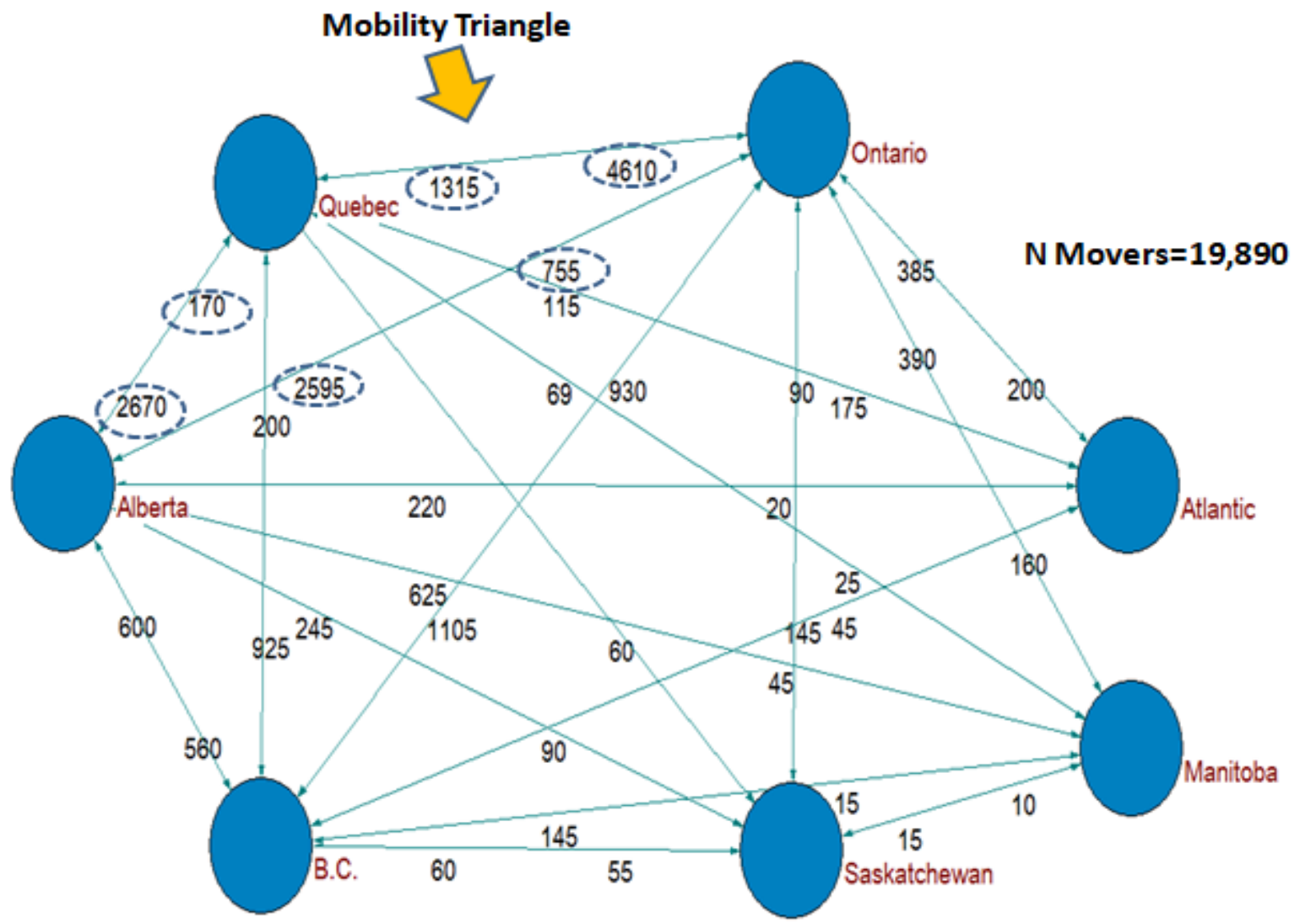

* Encircled:=mobility triangle constituents. Source: Special Table SCS-504, Longitudinal Immigration Database (IMDB).

${ }_{12}$ Social network graphs are graphical devices used to detect and interpret patterns of links or ties among units of analysis (deNooy et.al. 2005)

13 Other major dyads of the migratory exchanges network found were: Ontario-B.C. (8\%), Quebec-B.C. (6\%) and Alberta-B.C. (6\%). 
Table 4 displays the various origins and destinations in percentages of Latino tax filers by gender and immigrant intake class categories. The figures in the table suggest that the participation in the AlbertaOntario-Quebec regions mobility triangle was higher among males (64\%) compared to that of females (58\%). This participation was found the highest among economic class principal applicants (76\%) and refugees (73\%). About $42 \%$ of the movement of economic class principal applicants during the observation period consisted of inflows from Quebec to Ontario. In the case of refugees, 48\% of its movement consisted of inflows from Quebec to Alberta and Ontario to Alberta. In the case of economic class spouses and dependents, 27\% of its movement consisted of inflows from Quebec to Ontario while, for family class immigrants, the inflows from Ontario to Alberta (16\%) and Quebec to Ontario (15\%) were the most noticeable.

Table 4: Latin American Immigrant Tax Filers: Regional Origins and Destinations (\%) of Movers by Gender and Immigrant Class, Tax Year 2014, 2000-2014 Landings

\begin{tabular}{|c|c|c|c|c|c|c|c|}
\hline$O / D$ & Both Genders & Males & Females & $\begin{array}{c}\text { Economic: } \\
\text { PA }\end{array}$ & $\begin{array}{l}\text { Economic: } \\
\text { SD }\end{array}$ & Family & Refugee \\
\hline$N^{*}$ & 19,890 & 9,810 & 10,080 & 6,045 & 4,145 & 4,300 & 5,300 \\
\hline Quebec to Ontario(t) & $23 \%$ & $23 \%$ & $24 \%$ & $42 \%$ & $27 \%$ & $15 \%$ & $16 \%$ \\
\hline Quebec to Alberta(t) & $13 \%$ & $15 \%$ & $12 \%$ & $15 \%$ & $15 \%$ & $6 \%$ & $24 \%$ \\
\hline Ontario to Alberta (t) & $13 \%$ & $15 \%$ & $11 \%$ & $8 \%$ & $9 \%$ & $16 \%$ & $24 \%$ \\
\hline Ontario to Quebec (t) & $7 \%$ & $7 \%$ & $6 \%$ & $6 \%$ & $7 \%$ & $11 \%$ & $7 \%$ \\
\hline Ontario to B.C. & $6 \%$ & $6 \%$ & $5 \%$ & $5 \%$ & $7 \%$ & $6 \%$ & $6 \%$ \\
\hline Quebec to B.C. & $5 \%$ & $5 \%$ & $4 \%$ & $8 \%$ & $6 \%$ & $3 \%$ & $5 \%$ \\
\hline BC to Ontario & $4 \%$ & $4 \%$ & $4 \%$ & $6 \%$ & $6 \%$ & $6 \%$ & $2 \%$ \\
\hline Alberta to Ontario (t) & $4 \%$ & $3 \%$ & $4 \%$ & $4 \%$ & $5 \%$ & $5 \%$ & $2 \%$ \\
\hline Manitoba to Alberta & $3 \%$ & $3 \%$ & $3 \%$ & $0 \%$ & $2 \%$ & $3 \%$ & $2 \%$ \\
\hline Alberta to B.C. & $3 \%$ & $2 \%$ & $2 \%$ & $2 \%$ & $6 \%$ & $6 \%$ & $1 \%$ \\
\hline Manitoba to Ontario & $2 \%$ & $2 \%$ & $2 \%$ & $0 \%$ & $2 \%$ & $2 \%$ & $0 \%$ \\
\hline Atlantic to Ontario & $2 \%$ & $2 \%$ & $2 \%$ & $0 \%$ & $1 \%$ & $3 \%$ & $2 \%$ \\
\hline Saskatchewan to Alberta & $1 \%$ & $1 \%$ & $1 \%$ & $0 \%$ & $2 \%$ & $2 \%$ & $1 \%$ \\
\hline Atlantic to Alberta & $1 \%$ & $1 \%$ & $1 \%$ & $0 \%$ & $0 \%$ & $1 \%$ & $2 \%$ \\
\hline B.C. to Quebec & $1 \%$ & $1 \%$ & $0 \%$ & $0 \%$ & $2 \%$ & $2 \%$ & $0 \%$ \\
\hline Alberta to Quebec (t) & $1 \%$ & $1 \%$ & $1 \%$ & $1 \%$ & $1 \%$ & $1 \%$ & $0 \%$ \\
\hline Manitoba to B.C. & $1 \%$ & $1 \%$ & $1 \%$ & $0 \%$ & $1 \%$ & $1 \%$ & $0 \%$ \\
\hline Atlantic to Quebec & $1 \%$ & $1 \%$ & $0 \%$ & $0 \%$ & $0 \%$ & $0 \%$ & $1 \%$ \\
\hline B.C. to Alberta & $3 \%$ & $3 \%$ & $2 \%$ & $2 \%$ & $3 \%$ & $6 \%$ & $2 \%$ \\
\hline Other O/Ds & $7 \%$ & $5 \%$ & $13 \%$ & $1 \%$ & $0 \%$ & $7 \%$ & $2 \%$ \\
\hline Total & $100 \%$ & $100 \%$ & $100 \%$ & $100 \%$ & $100 \%$ & $100 \%$ & $100 \%$ \\
\hline
\end{tabular}

* Rounded adjusted figures. Symbols: $\mathrm{PA}=$ principal applicant, $\mathrm{SD}=$ spouses and dependants, $(\mathrm{t})=$ mobility triangle constituent, Source: Special Table SCS-504, Longitudinal Immigration Database (IMDB). 
Table 5 displays similar figures as Table 4 but broken down by the country of citizenship of Latino tax filers. The participation of tax filers in the Alberta-Ontario-Quebec mobility triangle, in descending order, was as follows: Venezuela (88\%), Cuba (81\%), Colombia (80\%), Peru (73\%) Brazil (62\%), Argentina (60\%), Mexico (55\%) and El Salvador (41\%). Other interesting numbers were drawn from the table and refer to the departure of Venezuelans to Ontario (40\%) and the departure of El Salvadoreans from Manitoba for Alberta (38\%) and from Ontario for Alberta (23\%). Overall, these figures reveal a very dynamic pattern of interregional mobility for Latino immigrants who were exposed to various push-pull pressures during the period 2000-2014.

Table 5: Latin American Immigrant Tax Filers: Regional Origins and Destinations (\%) of Movers by Countries of Citizenship, tax year 2014, 2000-2014 Landings

\begin{tabular}{|c|c|c|c|c|c|c|c|c|c|}
\hline$O / D$ & $\begin{array}{l}0 \\
0 \\
0 \\
0 \\
0 \\
0 .\end{array}$ & $\begin{array}{l}\frac{3}{2} \\
\frac{1}{2} \\
0\end{array}$ & 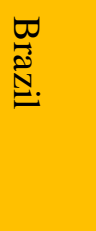 & Ð & 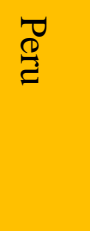 & $\begin{array}{l}\underset{D}{D} \\
\stackrel{D}{D} \\
\stackrel{D}{D} \\
\frac{D}{D}\end{array}$ & 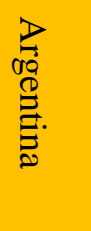 & 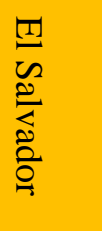 & 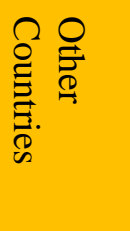 \\
\hline$N^{*}$ & 7,530 & 4,340 & 1,710 & 940 & 1,335 & 1,330 & 990 & 740 & 965 \\
\hline Quebec to Ontario (t) & $31 \%$ & $22 \%$ & $31 \%$ & $29 \%$ & $28 \%$ & $40 \%$ & $30 \%$ & $8 \%$ & $28 \%$ \\
\hline Ontario to Quebec (t) & $22 \%$ & $6 \%$ & $8 \%$ & $20 \%$ & $13 \%$ & $5 \%$ & $8 \%$ & $0 \%$ & $10 \%$ \\
\hline Ontario to Alberta (t) & $17 \%$ & $12 \%$ & $9 \%$ & $17 \%$ & $10 \%$ & $16 \%$ & $8 \%$ & $23 \%$ & $14 \%$ \\
\hline Atlantic to Ontario & $9 \%$ & $0 \%$ & $1 \%$ & $9 \%$ & $2 \%$ & $1 \%$ & $1 \%$ & $0 \%$ & $3 \%$ \\
\hline Quebec to Alberta (t) & $8 \%$ & $11 \%$ & $7 \%$ & $8 \%$ & $17 \%$ & $18 \%$ & $7 \%$ & $0 \%$ & $9 \%$ \\
\hline B.C. to Ontario & $6 \%$ & $6 \%$ & $9 \%$ & $6 \%$ & $6 \%$ & $3 \%$ & $9 \%$ & $0 \%$ & $6 \%$ \\
\hline Ontario to B.C. & $4 \%$ & $6 \%$ & $9 \%$ & $4 \%$ & $5 \%$ & $0 \%$ & $9 \%$ & $10 \%$ & $6 \%$ \\
\hline Quebec to B.C. & $2 \%$ & $7 \%$ & $6 \%$ & $2 \%$ & $4 \%$ & $3 \%$ & $6 \%$ & $0 \%$ & $4 \%$ \\
\hline Alberta to Ontario (t) & $2 \%$ & $3 \%$ & $6 \%$ & $2 \%$ & $5 \%$ & $7 \%$ & $6 \%$ & $0 \%$ & $4 \%$ \\
\hline B.C. to Quebec & $1 \%$ & $2 \%$ & $1 \%$ & $1 \%$ & $1 \%$ & $0 \%$ & $1 \%$ & $0 \%$ & $1 \%$ \\
\hline Atlantic to Quebec & $0 \%$ & $0 \%$ & $0 \%$ & $0 \%$ & $0 \%$ & $0 \%$ & $0 \%$ & $0 \%$ & $0 \%$ \\
\hline Atlantic to Alberta & $0 \%$ & $1 \%$ & $0 \%$ & $0 \%$ & $5 \%$ & $0 \%$ & $0 \%$ & $0 \%$ & $1 \%$ \\
\hline Manitoba to Ontario & $0 \%$ & $2 \%$ & $2 \%$ & $0 \%$ & $0 \%$ & $0 \%$ & $2 \%$ & $13 \%$ & $2 \%$ \\
\hline Manitoba to Alberta & $0 \%$ & $3 \%$ & $0 \%$ & $0 \%$ & $0 \%$ & $0 \%$ & $1 \%$ & $38 \%$ & $5 \%$ \\
\hline Manitoba to B.C. & $0 \%$ & $0 \%$ & $0 \%$ & $0 \%$ & $0 \%$ & $0 \%$ & $0 \%$ & $2 \%$ & $0 \%$ \\
\hline $\begin{array}{l}\text { Saskatchewan to } \\
\text { Alberta }\end{array}$ & $0 \%$ & $2 \%$ & $1 \%$ & $0 \%$ & $0 \%$ & $0 \%$ & $1 \%$ & $0 \%$ & $0 \%$ \\
\hline Alberta to Quebec (t) & $0 \%$ & $1 \%$ & $1 \%$ & $0 \%$ & $0 \%$ & $2 \%$ & $1 \%$ & $0 \%$ & $0 \%$ \\
\hline Alberta to B.C. & $0 \%$ & $5 \%$ & $3 \%$ & $0 \%$ & $3 \%$ & $2 \%$ & $3 \%$ & $0 \%$ & $2 \%$ \\
\hline B.C. to Alberta & $0 \%$ & $5 \%$ & $4 \%$ & $0 \%$ & $2 \%$ & $3 \%$ & $4 \%$ & $6 \%$ & $3 \%$ \\
\hline Other O/Ds & $0 \%$ & $5 \%$ & $3 \%$ & $0 \%$ & $0 \%$ & $3 \%$ & $4 \%$ & $0 \%$ & $2 \%$ \\
\hline Total & $100 \%$ & $100 \%$ & $100 \%$ & $100 \%$ & $100 \%$ & $100 \%$ & $100 \%$ & $100 \%$ & $100 \%$ \\
\hline
\end{tabular}




\subsection{Post-Exploration Reflections}

Before discussing the findings of this analysis, it is important to mention some shortcomings present in the data and the scope of analysis. Firstly, the mobility behaviour of Latino immigrants was observed for aggregated yearly single cohorts (three arrival cohorts) fixed at one point of observation (tax year 2014). This "snapshot" approach made it difficult to evaluate how each yearly cohort changed their migratory behavior at specific points in time. Several moves could have also occurred between the tax year observation points. Secondly, information on inter-city (e.g. to Toronto, Montreal, Vancouver, and other cities in the West), as well as intraregional mobility, was not available in the IMDB table. Geographical regions do not "attract" or "repel" immigrants, major cities in regions do (Trovato, 2009). Thirdly, it should be noted, that the reasons why tax filers changed their place of residence since their arrival to Canada remain unknown. Data from focused surveys and qualitative research can reveal this aspect in more detail.

The 2000-2014 period represents an important historical juncture for Latin American immigration to Canada. During this time, the fifth wave migratory wave (named "technological-professional"), which was originally triggered in the mid-1990s, brought thousands of citizens from countries such as Colombia, Mexico, Venezuela, Cuba, and Brazil to Canada. Immigrants from these countries are escaping political and economic instability, ecological and health crises, rising social conflict, and deep socio-economic restructuring in their home countries (ECLAC, 2019). The fifth Latino wave succeeded in time the Central American one which mostly dominated the immigration picture in the 1980s. Members of the fifth wave constitute a very diverse group of migrants ranging

from highly skilled economic entrants to lower ones comprising temporary workers, visitors, and asylum seekers who later regularize their status in Canada. For many immigrants of the fifth wave (and for members of the previous ones), interregional migration in Canada may be a necessary second step of the migratory journey. It entails moving away from their original landing destination and searching for places that could fulfill their personal goals, which may include the pursuit of better employment opportunities, affordable housing, better health, better climate, access to friends and family, linguistic familiarity, and even lifestyle-related amenities.

Overall, the exploration of retention and net migration rates of Latino immigrant tax filers presents us with a dynamic picture of interregional mobility taking place in Canada after arrival. The departure from the Atlantic and/or Quebec regions and the trek to destinations such as Alberta or British Columbia were found to be major migratory patterns present in the IMDB tax filer data. By the tax year 2014, 20\% of all tax filers arriving in Canada between 2000-2014, had moved out of their intended region of landing. Among the most mobile groups of the period, the data identified males, earlier arrival cohort members, those with higher educational levels, economic principal applicants, and Colombian citizens. The regional triangle constituted by Alberta, Ontario, and Quebec was also found to be the most dominant in the network of migratory exchanges (61\%). Within this mobility triangle, the movement from Quebec to Ontario was the more prominent one (23\%). Movements from Quebec and Ontario to Alberta were also noticeable (13\% each). Alberta was the typical regional "winner" of both economic class principal applicant and refugee class inflows while the Atlantic region, Quebec and Manitoba stood as relative "losers". Ontario and Saskatchewan retained some form of migratory balance in terms of inflows and outflows of their regions. Overall, the data suggest that the migratory patterns of Latin 
American immigrants did not differ substantially from those of the general immigrant population described in previous reports. However, significant intra-group variations found in terms of gender, immigrant intake class and nationalities also suggest that all Latino immigrants had the same level of responsiveness to the various push and pull pressures of interregional migration during 2000-2014.

The exploratory findings of the paper raise some interesting discussion points of reflection. The first point refers to the slight overrepresentation of women in the pool of tax filers captured by the IMDB dataset. This finding directly reflects the gender composition of the immigrant inflows from Latin America to Canada ${ }^{14}$ rather than gender role responsibilities in tax filing reporting. The second reflection point refers to the pattern of migration from the East to the West direction. While the migration from the Atlantic provinces may be explained by smaller population sizes and limited employment opportunities, the migration from the Quebec region to Ontario deserves some attention. This migratory movement may be partly explained by the geographical distance between metropolitan Montreal (Quebec) and Toronto (Ontario): 542 kilometers. A shorter distance offers a great opportunity for quick resettlement for Latino immigrants. However, linguistic milieu considerations and proximity to major ethnic enclaves cannot be discounted as drivers playing some roles in migratory decisions. A third reflection point refers to the vitality of Latino refugee inter-regional migration. Refugees were found as mobile as economic class entrants suggesting that they may be as sensitive to labour market conditions outside their original provinces of landing (e.g. Alberta) as their economic class counterparts. Almost half (48\%) of the migratory movement of Latino refugees consisted of flows from Ontario and Quebec to Alberta. Pull-related factors may have been decisive in this respect.

A fourth, and perhaps the most interesting, reflection point concerns the special case of Colombian citizens who were found as the most inter-regionally mobile individuals during the observation period. About 28\% had left their original region of landing by tax year 2014. Colombians are a representative case of the fifth historical wave of Latino immigration to Canada. More than half of them (54\%) entered Canada as refugees (the vast majority as protected persons) while $44 \%$ entered as economic class and $29 \%$ as family class ones. Moderate to high human capital endowments were observed for this group: $55 \%$ arrived with an educational level equivalent to a bachelor's or higher education degree. These findings, perhaps, point in the direction of both education and familiarity with the Canadian labour market conditions as potential drivers of interregional mobility for Colombians. Again, data from focused surveys and qualitative research is necessary to reveal hidden aspects about this phenomenon.

Tracking the patterns of interregional mobility among Latin American immigrants to Canada after their arrival to the country provides interesting insights into how this particular population is redistributed, how it responds to the needs of regional economies, and also speaks to the success of immigrant integration and resettlement of Latin American immigrants in particular regions of Canada. Latino immigrants are moving to Canadian regions where their main "desires and aspirations" are perceived most likely to be fulfilled (Van Hear et. al.,

\footnotetext{
14 Using 2016 Census data, a study of 25 major ethnic immigrant inflows from Latin America to Canada found that $56 \%$ of individual counts corresponded to female immigrants. Proportions were the highest among Peruvian, Ecuadorian, Venezuelan and Brazilian inflows (Mata, 2020).
} 
2018). Today, considerable investments are presently made by local, provincial, and federal government agencies to welcome and integrate Latin American immigrants as potential long-time residents. However, if the initial place of residence does not meet occupational and housing expectations, there is no ability to navigate through local/provincial or federal bureaucracies and no community support for families and their children, Latin American immigrants will, eventually, find other more "suitable" residential destination in Canada. Their migratory journey may lead them to resettle multiple times at different locations, which may include metropolitan or non-metropolitan centers situated in regions such as smaller cities, towns, or even rural areas.

\subsection{References}

Amirault, G., de Munnick, D., and Miller, S. (Spring 2013). Explaining Canada's Regional Migration Patterns. Bank of Canada Review.

Armony, Victor. 2014. "Latin American Communities in Canada: Trends in Diversity and Integration." Canadian Ethnic Studies 46 (3): 7-34. https://doi.org/10.1353/ces.2014.0043

Aslund, O., and Olof-Rooth, D. (2007). Do When and Where Matter? Initial Labour Market Conditions and Immigrant Earnings. The Economic Journal, 117 (March), pp 422-448.

Bonikowska, A., Hou, F., and Picot, G. (2015). Changes in the Regional Distribution of New Immigrants to Canada. Analytical Studies Branch Research Paper Series, Statistics Canada, Catalogue no. 11F0019M —No. 366 ISSN 1205-9153, ISBN 978-1-100-25751-8.

Chiswick, B.R., and Miller., P.W. (2005). Do Enclaves Matter in Immigrant Adjustment? City and Community 4 (1): pp 5-35.

Courgeau, D. (1995). Migration Theories of the Mobility Process. International Journal of Population Geography (1): pp 19-27

Dahl, M. and Sorensen, O. (2010). The Social Attachment to Place. Social Forces 89(2): pp 633-658 de Nooy, W., Mrvar, A., and Batajeli, V. (2005). Exploratory Social Network Analysis with Pajek. Cambridge University Press

ECLAC- Economic Commission for Latin America and the Caribbean (2019), Social Panorama of Latin America, 2018, (LC/PUB.2019/3-P), Santiago, 2019.CEPAL.

Hou, F. (2005). The Initial Destinations and Redistribution of Canada's Major Immigrant Groups: Changes over the Past Two Decades. Analytical Studies Branch Research Paper Series, Statistics Canada, SSN: 1205-9153 ISBN: 0-662-40761

Houle, R. (2007). Secondary Migration of New Immigrants to Canada. Our Diverse Cities (3), pp 15-24.

IRCC-Immigration, Refugees and Citizenship Canada (2017): Facts and Figures 2017, Permanent Residents by Countries of Citizenship, Ottawa, p.21

Garay, E. (2000). Social economic and demographic profile of the Hispanic community. Toronto: Hispanic Development Council.

Goldring, L., and Landolt, P.. (2011). "Caught in the Work-Citizenship Matrix: the Lasting Effects of Precarious Legal Status on Work for Toronto Immigrants." Globalizations 8 (3):325-341.

Luin Goldring and Patricia Landolt (2021): From illegalised migrant toward permanent resident: assembling precarious legal status trajectories and differential inclusion in Canada, Journal of Ethnic and Migration Studies, DOI: 10.1080/1369183X.2020.1866978 
Nogle, J.M. (1994). Internal Migration for Recent Immigrants to Canada. International Migration Review (28): pp 31-48

Mata, F. (1985). Latin American Immigration to Canada: Some Reflections on the Immigration Statistics. Canadian Journal of Latin American and Caribbean Studies, 10, no. 20 (1985): 27-42.

Mata, F. (2020). Exploring the Ethnic Immigrant Inflows from Latin America to Canada: 1981-2016. Paper presented at the 2020 REDAN-UNAM conference, Mexico City, May 18-20.

Orrenius, P., \& Zavodny, M. (2009). Tied to the Business Cycle: how Immigrants Fare in good and bad Economic Times. Washington D C: Migration Policy Institute.

Okonny-Myers, I. (2010). The Interprovincial Mobility of Immigrants in Canada. Citizenship and Immigration Canada, Ci4- 47/2010E-PDF 978-1-100-16547-9

Richmond, A.H. (1988). Sociological Theories of International Migration, Current Sociology, pp. 7-25.

Simmons, A. (2010). Immigration and Canada: Global and Transnational Perspectives, Canadian Scholars Press.

Trovato, F. (2009). Canada's Population in a Global Context: An Introduction to Social Demography, Oxford University Press

Van Hear N; Bakewell,O and Long. K (2018) Push-pull plus: reconsidering the drivers of migration, Journal of Ethnic and Migration Studies, 44:6, 927-944, DOI: 10.1080/1369183X.2017.1384135

Van Huystee, M. (2016): Interprovincial Mobility: Retention Rates and Net Inflow Rates 2008-2013 Landings

Policy Research Division, IRCC, 978-0-660-09389-5 publication, Reference Number: R33-2016

Veronis, L. (2010): Immigrant Participation in the Transnational Era: Latin Americans' Experiences with Collective Organising in Toronto, Journal of International Migration and Integration 11(2):173-192

Zavodny, M. (1999). Determinants of Recent Immigrants' Locational Choices. Inter-national Migration Review. 33: pp. 1014- 1030. 


\section{APPENDIX: CHARTS AND TABLES}

Chart A-1: Latin American Immigrant Taxfilers: Intended Regions of Landing , tax year 2014 ,2000-2014 Landings

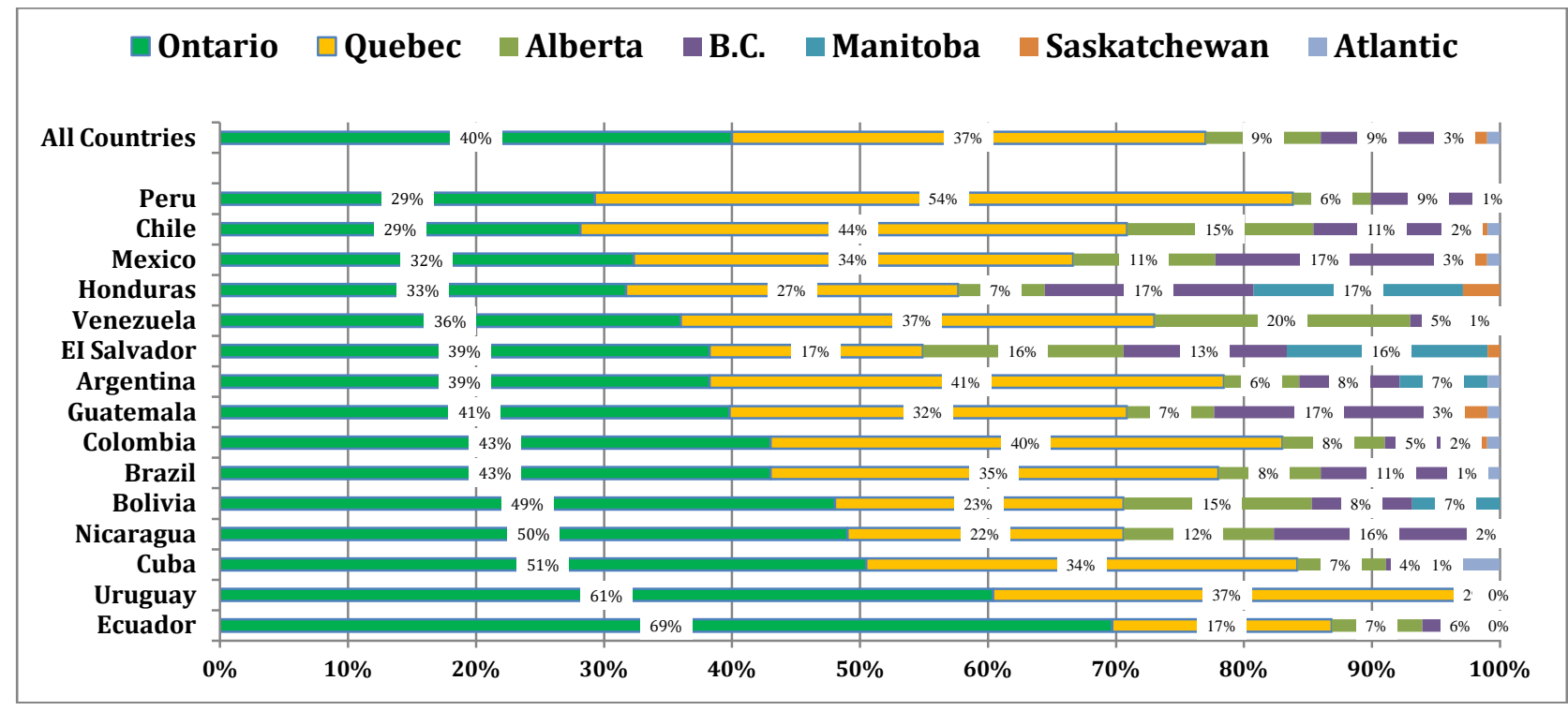

Source: Special Table SCS-504, Longitudinal Immigration Database (IMDB).

Chart A-2: Latin American Immigrant Taxfilers: Median Employment Incomes (thousands \$Can, ranked ) by Gender and Countries of Citizenship. tax year 2014, 2000-2014 Landings

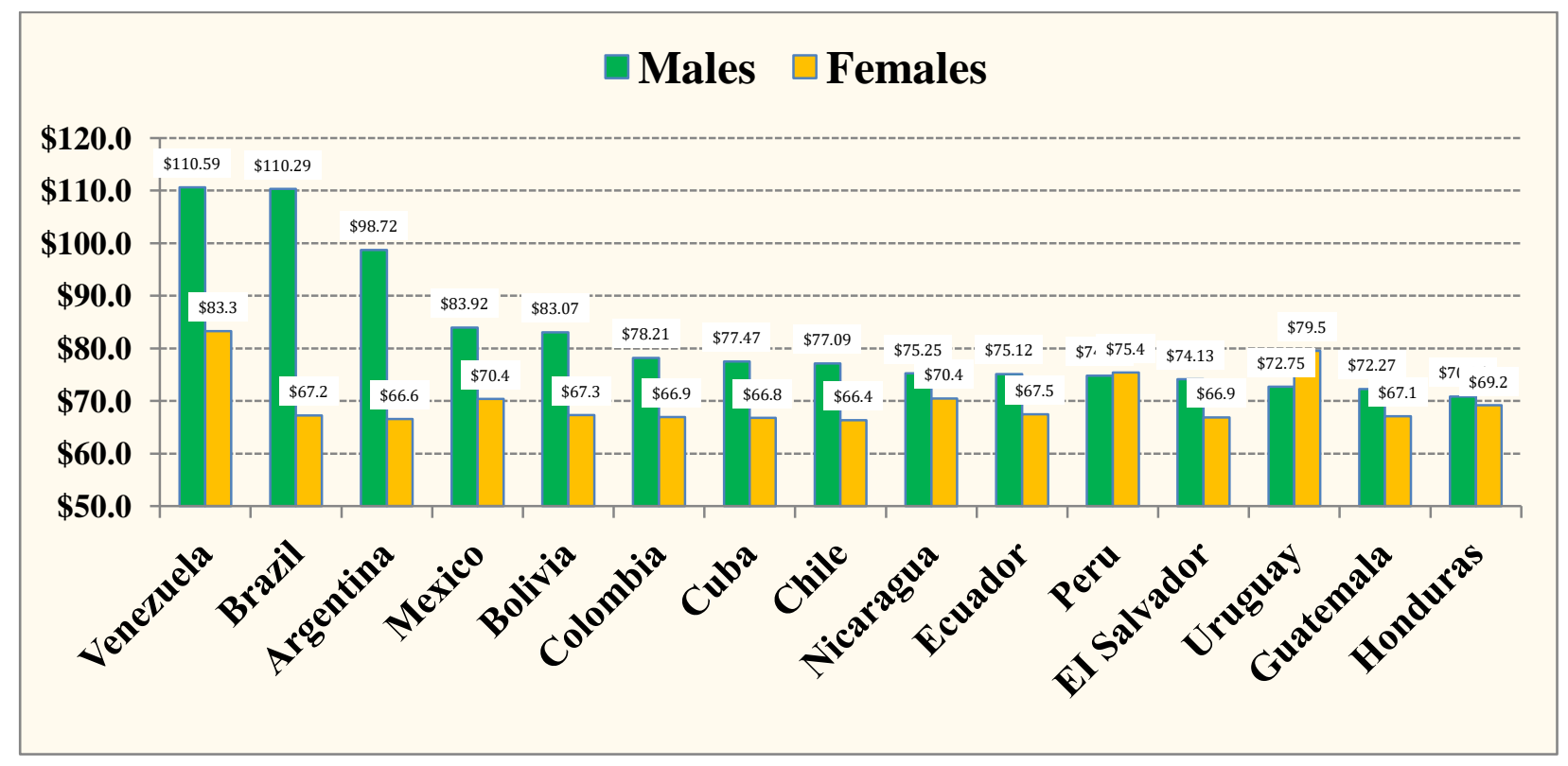

Source: Special Table SCS-504, Longitudinal Immigration Database (IMDB). 
Table A-1: Interprovincial Mobility of Latin American Immigrant Taxfilers: Retention Rates and Net migration rates, MALES , tax year 2014, 2000-2014 Landings

\begin{tabular}{|l|r|r|r|r|r|r|r|}
\hline Male Taxfilers & $\begin{array}{c}\text { Destined at Landing } \\
\text { (a) }\end{array}$ & $\begin{array}{c}\text { In- } \\
\text { migration } \\
\text { (b) }\end{array}$ & $\begin{array}{c}\text { Out-Migration } \\
\text { (c) }\end{array}$ & $\begin{array}{c}\text { Net } \\
\text { Migration } \\
\text { (d)=(b)-(c) }\end{array}$ & $\begin{array}{c}\text { Destined } \\
\text { and } \\
\text { Residing } \\
\text { TX 2014 }\end{array}$ & $\begin{array}{c}\text { RR; } \\
\text { Retention } \\
\text { Rates } \\
(\mathrm{e}) /(\mathrm{a})\end{array}$ & $\begin{array}{c}\% \text { NMR: } \\
((\mathrm{d}) /(\mathrm{a})) \times 100\end{array}$ \\
\hline Atlantic & 560 & 130 & 250 & -120 & 300 & 0.53 & $-21.5 \%$ \\
\hline Quebec & 16,965 & 595 & 2,795 & $-2,200$ & 14,240 & 0.84 & $-13.0 \%$ \\
\hline Ontario & 18,485 & 2,140 & 1,955 & 185 & 16,600 & 0.90 & $1.0 \%$ \\
\hline Manitoba & 1,405 & 55 & 375 & -320 & 1,000 & 0.71 & $-22.5 \%$ \\
\hline Saskatchewan & 331 & 100 & 75 & 25 & 220 & 0.67 & $6.7 \%$ \\
\hline Alberta & 4,025 & 2,475 & 430 & 2,045 & 3,570 & 0.89 & $50.8 \%$ \\
\hline \hline British Columbia & 3,650 & 865 & 490 & 375 & 3,135 & 0.86 & \\
\hline
\end{tabular}

Source: Special Table SCS-504, Longitudinal Immigration Database (IMDB).

Table A-2: Interprovincial Mobility of Latin American Immigrant Taxfilers: Retention Rates and Net migration rates, FEMALES , tax year 2014, 2000-2014 Landings

\begin{tabular}{|l|r|r|r|r|r|r|r|}
\hline Female Taxfilers & \multicolumn{1}{c}{$\begin{array}{c}\text { Destined at } \\
\text { Landing } \\
\text { (a) }\end{array}$} & $\begin{array}{c}\text { In- } \\
\text { migration } \\
\text { (b) }\end{array}$ & $\begin{array}{c}\text { Out- } \\
\text { Migration } \\
\text { (c) }\end{array}$ & $\begin{array}{c}\text { Net } \\
\text { Migration } \\
\text { (d)=(b)-(c) }\end{array}$ & $\begin{array}{c}\text { Destined } \\
\text { and } \\
\text { Residing } \\
\text { TX 2014 }\end{array}$ & $\begin{array}{c}\text { RR; } \\
\text { Retention } \\
\text { Rates } \\
\text { (e)/(a) }\end{array}$ & $\begin{array}{c}\text { \% NMR: } \\
\text { ((d)/(a))x100 }\end{array}$ \\
\hline Atlantic & 655 & 160 & 265 & -105 & 345 & 0.53 & $-16.4 \%$ \\
\hline Quebec & 19,490 & 615 & 2,695 & $-2,080$ & 16,910 & 0.87 & $-10.7 \%$ \\
\hline Ontario & 20,300 & 2,445 & 1,643 & 802 & 17,775 & 0.88 & $4.0 \%$ \\
\hline Manitoba & 1,460 & 100 & 430 & -330 & 1,120 & 0.77 & $-22.5 \%$ \\
\hline Saskatchewan & 525 & 135 & 185 & -50 & 440 & 0.84 & $-9.7 \%$ \\
\hline Alberta & 5,605 & 2,045 & 640 & 1,405 & 5,440 & 0.97 & $25.1 \%$ \\
\hline \hline British Columbia & 4,935 & 990 & 635 & 355 & 4,465 & & 0.90 \\
\hline
\end{tabular}

Source: Special Table SCS-504, Longitudinal Immigration Database (IMDB).

Table A-3: Interprovincial Mobility of Latin American Immigrant Taxfilers: Retention Rates and Net migration rates, ECONOMIC CLASS PRINCIPAL APPLICANTS, tax year 2014, 2000-2014 Landings

\begin{tabular}{|l|r|r|r|r|r|r|r|}
\hline $\begin{array}{l}\text { Economic Class: } \\
\text { Principal Applicant }\end{array}$ & $\begin{array}{c}\text { Destined at } \\
\text { Landing } \\
\text { (a) }\end{array}$ & $\begin{array}{c}\text { In- } \\
\text { migration } \\
\text { (b) }\end{array}$ & $\begin{array}{c}\text { Out-Migration } \\
\text { (c) }\end{array}$ & $\begin{array}{c}\text { Net } \\
\text { Migration } \\
\text { (d)=(b)-(c) }\end{array}$ & $\begin{array}{c}\text { Destined } \\
\text { and } \\
\text { Residing } \\
\text { TX 2014 } \\
\text { (e) }\end{array}$ & $\begin{array}{c}\text { RR; } \\
\text { Retention } \\
\text { Rates } \\
(\mathrm{e}) /(\mathrm{a})\end{array}$ & $\begin{array}{c}\% \text { NMR: } \\
((\mathrm{d}) /(\mathrm{a})) \mathrm{x} \\
100\end{array}$ \\
\hline Atlantic & 125 & 80 & 15 & 65 & 70 & 0.55 & $51.6 \%$ \\
Quebec & 14,100 & 285 & 2,680 & -2395 & 10,955 & 0.78 & $-17.0 \%$ \\
Ontario & 6,395 & 2,055 & 830 & 1,225 & 5,530 & 0.86 & $19.1 \%$ \\
Manitoba & 125 & 5 & 15 & -10 & 65 & 0.48 & $-3.2 \%$ \\
Saskatchewan & 40 & 5 & 0 & 5 & 5 & 0.20 & $20.0 \%$ \\
Alberta & 1,800 & 1,000 & 260 & 740 & 1,515 & 0.84 & $41.2 \%$ \\
British Columbia & 1,605 & 620 & 265 & 355 & 1,278 & 0.80 & $22.1 \%$ \\
\hline
\end{tabular}

Source: Special Table SCS-504, Longitudinal Immigration Database (IMDB). 
Table A-4: Interprovincial Mobility of Latin American Immigrant Taxfilers: Retention Rates and Net migration rates, ECONOMIC CLASS SPOUSES AND DEPENDANTS, tax year 2014, 2000-2014 Landings

\begin{tabular}{|c|c|c|c|c|c|c|c|}
\hline $\begin{array}{l}\text { Economic Class: } \\
\text { Spouses and } \\
\text { Dependents }\end{array}$ & $\begin{array}{l}\text { Destined at } \\
\text { Landing } \\
\text { (a) }\end{array}$ & $\begin{array}{l}\text { In- } \\
\text { migration } \\
\text { (b) }\end{array}$ & $\begin{array}{l}\text { Out-Migration } \\
\text { (c) }\end{array}$ & $\begin{array}{c}\text { Net } \\
\text { Migration } \\
\text { (d)=(b)-(c) }\end{array}$ & $\begin{array}{c}\text { Destined } \\
\text { and } \\
\text { Residing } \\
\text { TX } 2014 \\
\text { (e) }\end{array}$ & $\begin{array}{c}\text { RR; } \\
\text { Retention } \\
\text { Rates } \\
\text { (e)/(a) }\end{array}$ & $\begin{array}{c}\text { \% NMR: } \\
((\mathrm{d}) /(\mathrm{a})) \times 10 \\
0\end{array}$ \\
\hline Atlantic & 130 & 15 & 25 & -10 & 35 & 0.26 & $-5.1 \%$ \\
\hline Quebec & 7,255 & 155 & 1,325 & $-1,170$ & 5,895 & 0.81 & $-16.1 \%$ \\
\hline Ontario & 4,685 & 1,090 & 550 & 540 & 4,095 & 0.87 & $11.5 \%$ \\
\hline Manitoba & 105 & 0 & 5 & -5 & 55 & 0.52 & $-6.5 \%$ \\
\hline Saskatchewan & 20 & 0 & 0 & 0 & 0 & 0.00 & $0.0 \%$ \\
\hline Alberta & 1,400 & 635 & 175 & 460 & 1,190 & 0.85 & $33.0 \%$ \\
\hline British Columbia & 1,120 & 360 & 175 & 185 & 900 & 0.81 & $16.4 \%$ \\
\hline
\end{tabular}

Source: Special Table SCS-504, Longitudinal Immigration Database (IMDB).

Table A-5: Interprovincial Mobility of Latin American Immigrant Taxfilers: Retention Rates and Net migration rates, FAMILY CLASS, tax year 2014, 2000-2014 Landings

\begin{tabular}{|l|r|r|r|r|r|r|r|}
\hline & $\begin{array}{c}\text { Destined at } \\
\text { Landing } \\
\text { Family Class }\end{array}$ & $\begin{array}{c}\text { In- } \\
\text { migration } \\
\text { (b) }\end{array}$ & $\begin{array}{c}\text { Out-Migration } \\
\text { (c) }\end{array}$ & $\begin{array}{c}\text { Net } \\
\text { Migration } \\
\text { (d)=(b)-(c) }\end{array}$ & $\begin{array}{c}\text { Destined } \\
\text { and } \\
\text { Residing } \\
\text { TX 2014 } \\
\text { (e) }\end{array}$ & $\begin{array}{c}\text { RR; } \\
\text { Retention } \\
\text { Rates } \\
(\mathrm{e}) /(\mathrm{a})\end{array}$ & $\begin{array}{c}\text { \% NMR: } \\
((\mathrm{d}) /(\mathrm{a})) \mathrm{x} \\
100\end{array}$ \\
\hline Atlantic & & & & & & \\
Quebec & 450 & 40 & 95 & -55 & 305 & 0.68 & $-12.6 \%$ \\
Ontario & 9,065 & 335 & 585 & -250 & 8455 & 0.93 & $-2.8 \%$ \\
Manitoba & 14,470 & 765 & 915 & -150 & 13525 & 0.93 & $-1.1 \%$ \\
Saskatchewan & 755 & 55 & 120 & -65 & 600 & 0.80 & $-8.9 \%$ \\
Alberta & 365 & 65 & 65 & 0 & 240 & 0.66 & $0.0 \%$ \\
British Columbia & 3,560 & 830 & 345 & 485 & 3170 & 0.89 & $13.5 \%$ \\
\end{tabular}

Source: Special Table SCS-504, Longitudinal Immigration Database (IMDB).

Table A-6: Interprovincial Mobility of Latin American Immigrant Taxfilers: Retention Rates and Net migration rates, REFUGEE CLASS, tax year 2014, 2000-2014 Landings

\begin{tabular}{|l|r|r|r|r|r|r|r|}
\hline & $\begin{array}{c}\text { Destined at } \\
\text { Landing } \\
\text { (a) }\end{array}$ & $\begin{array}{c}\text { In- } \\
\text { migration } \\
\text { (b) }\end{array}$ & $\begin{array}{c}\text { Out-Migration } \\
\text { (c) }\end{array}$ & $\begin{array}{c}\text { Net } \\
\text { Migration } \\
\text { (d)=(b)-(c) }\end{array}$ & $\begin{array}{c}\text { Destined } \\
\text { and } \\
\text { Residing } \\
\text { TX 2014 } \\
\text { (e) }\end{array}$ & $\begin{array}{c}\text { RR; } \\
\text { Retention } \\
\text { Rates } \\
(\mathrm{e}) /(\mathrm{a})\end{array}$ & $\begin{array}{c}\% \text { NMR: } \\
(\mathrm{(d)} /(\mathrm{a})) \times 10 \\
0\end{array}$ \\
\hline Atlantic & & & & & & \\
Quebec & 315 & 20 & 160 & -140 & 120 & 0.38 & $-44.1 \%$ \\
Ontario & 9,610 & 235 & 1,305 & $-1,070$ & 8,275 & 0.86 & $-11.1 \%$ \\
Manitoba & 11,650 & 650 & 1,150 & -500 & 10,480 & 0.90 & $-4.3 \%$ \\
Saskatchewan & 290 & 15 & 75 & -60 & 180 & 0.64 & $-21.2 \%$ \\
Alberta & 190 & 25 & 25 & 0 & 105 & 0.55 & $0.0 \%$ \\
British Columbia & 1,370 & 1,620 & 90 & 1,530 & 1,250 & 0.91 & $111.6 \%$ \\
\end{tabular}

Source: Special Table SCS-504, Longitudinal Immigration Database (IMDB). 